\title{
THE PROTECTIVE AIR FILM OF AN EXTERIOR WINDOW
}

\author{
By

\section{Sanaz Dianat} \\ Bachelor of Civil Engineering, Ryerson University, 2017
}

\author{
A Major Research Project \\ Presented to Ryerson University \\ In Partial Fulfillment of the \\ Requirements for the Degree of \\ Master of Building Science (MBSc) \\ In the Graduate Program of Building Science
}

Toronto, Ontario, Canada, 2019

(C) Sanaz Dianat, 2019 


\section{Author's Declaration}

I hereby declare that I am the sole author of this MRP. This is a true copy of the MRP, including any required final revisions.

I authorize Ryerson University to lend this MRP to other institutions or individuals for the purpose of scholarly research.

I further authorize Ryerson University to reproduce this MRP by photocopying or by other means, in total or in part, at the request of other institutions or individuals for the purpose of scholarly research.

I understand that my MRP may be made electronically available to the public. 
The Protective Air Film of an Exterior Window

Sanaz Dianat, 2019

Master of Building Science

Ryerson University

\begin{abstract}
The research paper investigates the impact of a window's exterior air film on the assembly temperature. The exterior air film constitutes a vital portion of a window's insulating values. The air film increases the temperature of the window exterior pane to a temperature above ambient temperature. The air film also rises the interior glass temperature and reduces the heat transfer from the interior surface. According to computational fluid dynamics (CFD), the air film is removed in windy conditions, decreasing the window temperature on the outside as well as on the inside. The idea behind the project is to carry out an experimental procedure on three different windows to validate the CFD results, which indicates the effect of various wind speeds.
\end{abstract}

Keyword: Exterior air film, computational fluid dynamics, window assembly, wind speed 


\section{Acknowledgement}

This work would not have been possible without my professor and research advisor Dr. Ramani Ramakrishnan. I would like to thank him for his support and dedication towards encouraging me to further my education in building envelope. My interest in windows' thermal performance led me to study the protective air film of an exterior window. He always gave me reassurance and direction toward my goal. I truly enjoyed my time working on this project.

I would like to acknowledge Mark Driedger of ATA Architects, for initiating the project and providing CFD simulation results, and Alina Pisetskaya of ATA Architects, for providing instrumentation.

I would also like to thank Greg Labbe and Michal Bartosik for their support and guidance throughout my research project.

I would further like to thank my second advisor, Dr. Umberto Berardi, for his constructive feedback and guidance during the final stages of this major research project.

Lastly, I would like to thank my family, whose love and guidance are with me in whatever I pursue, and for always encouraging me to follow my dreams. To my friend, Paria Esmaeil Khorasani, for her help and support throughout this journey. This would not have been possible, without the help of all these wonderful people. 
Table of Contents

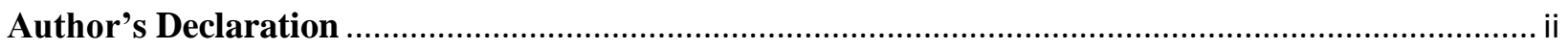

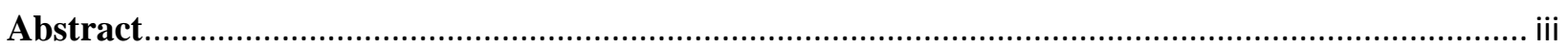

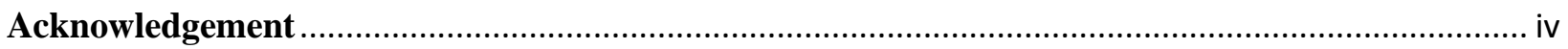

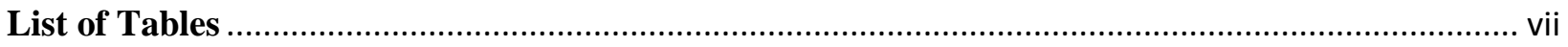

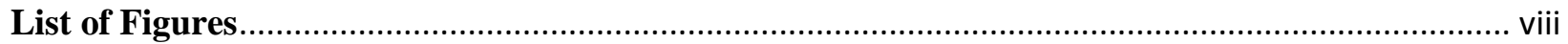

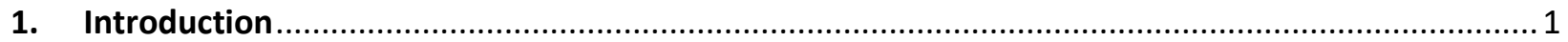

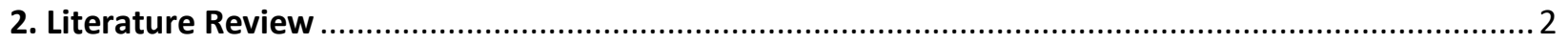

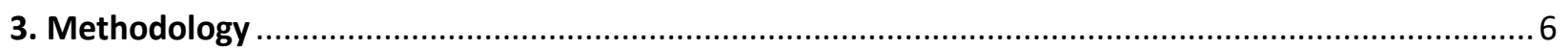

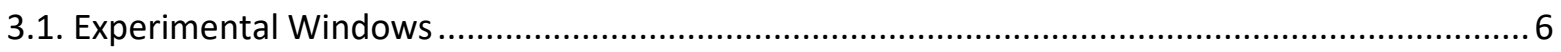

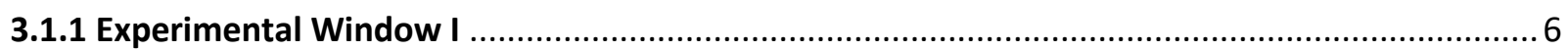

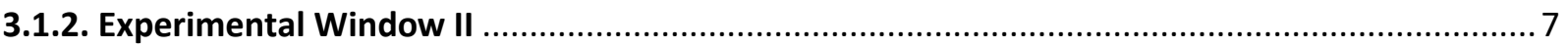

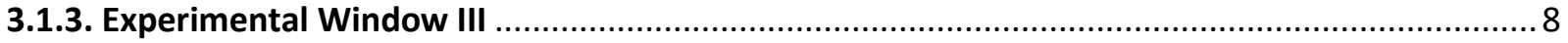

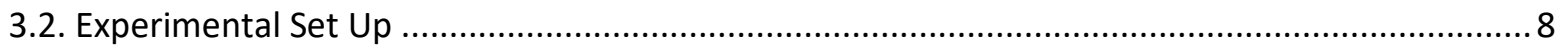

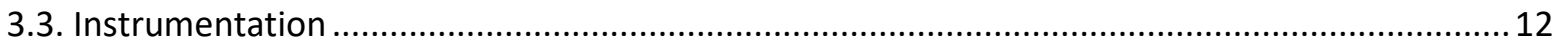

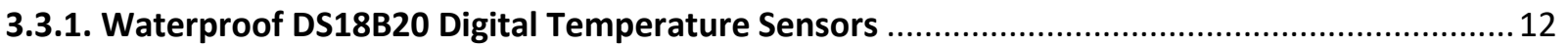

3.3.2. Data Logging Shield for Arduino UNO, Assembled, R3 Compatible ........................................13

3.3.3. Elegoo UNO R3 Board ATmega328P ATMEGA16U2 with USB Cable [for Arduino] ..................13

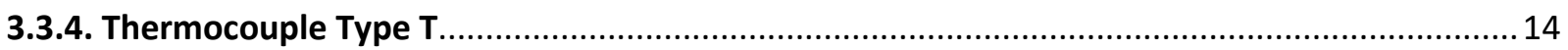

3.3.5. An Eight-Channel Thermocouple Temperature Recorder (OctTemp) ................................. 14

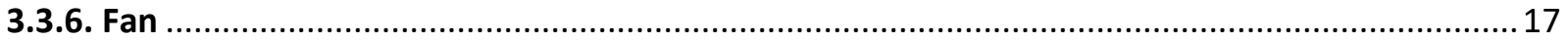

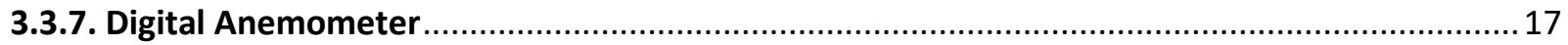

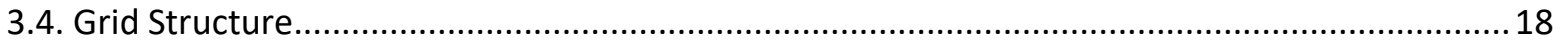

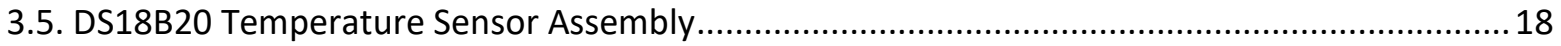

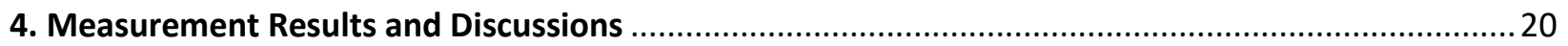

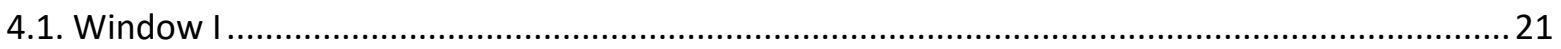

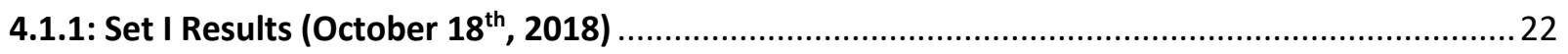

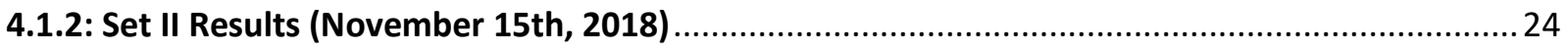

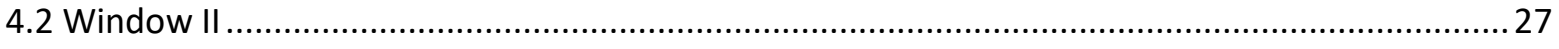

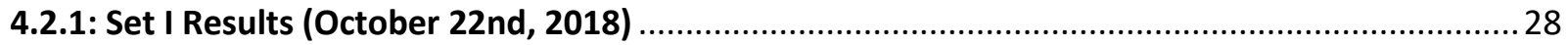

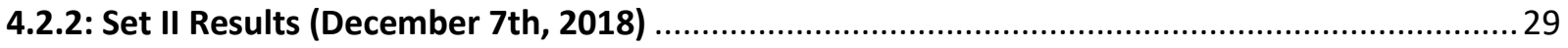

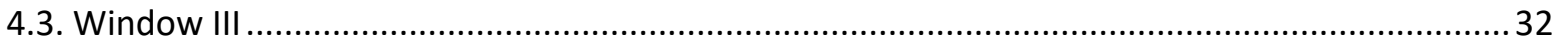




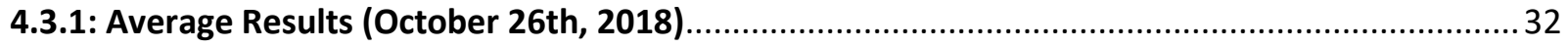

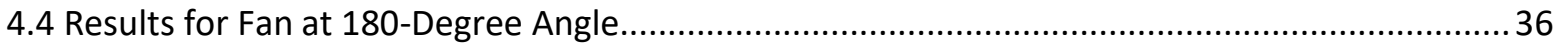

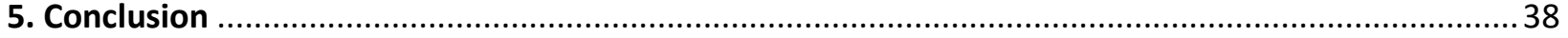

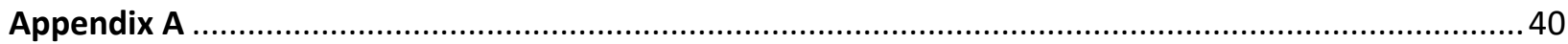

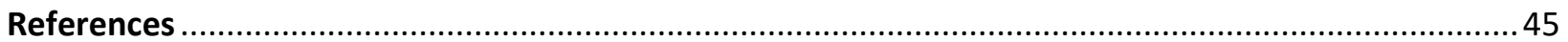




\section{List of Tables}

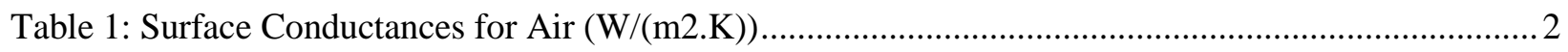

Table 2: Impact of Different Wind Speed on a Window's Surface Temperature ......................................5

Table 3: Window I Temperature Results (Positive Temperature) ...........................................................22

Table 4: Positive Temperature Data for Corner Sensors (Window I) .....................................................23

Table 5: Window I Temperature Results (Negative Temperature) …......................................................25

Table 6: Negative Temperature Data for Corner Sensors (Window I) ……….........................................26

Table 7: Window II Temperature Results (Positive Temperature) ….....................................................28

Table 8: Positive Temperature Data for Corner Sensors (Window II) ...................................................29

Table 9: Window II Temperature Results (Negative Temperature) …..................................................... 30

Table 10: Negative Temperature Data for Corner Sensors (Window II) ..................................................31

Table 11: Window III Temperature Results (Positive Temperature)........................................................ 32

Table 12: Positive Temperature Data for Corner Sensors (Window III) .................................................. 33

Table 13: Temperature Results for 180-Degree Air Flow (All Windows) ............................................... 36 


\section{List of Figures}

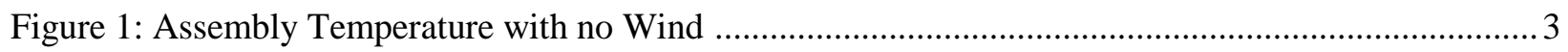

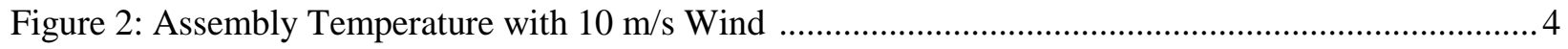

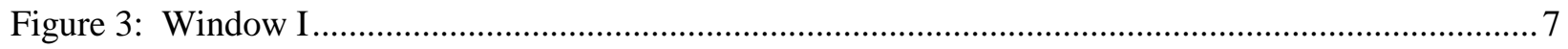

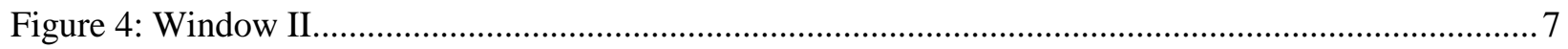

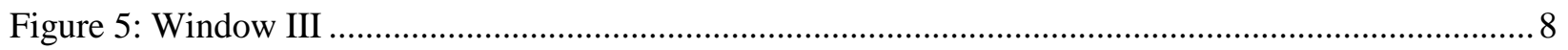

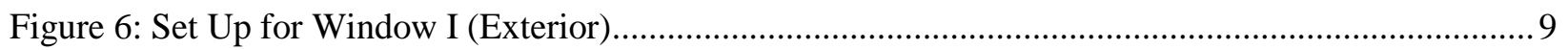

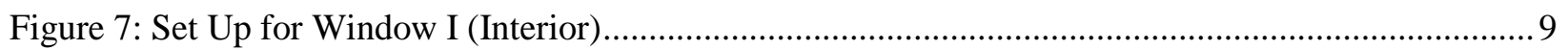

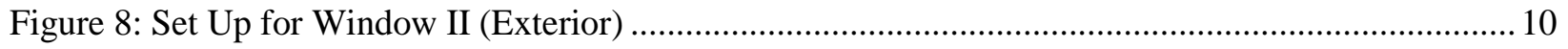

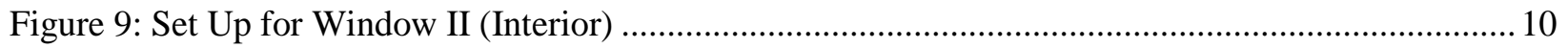

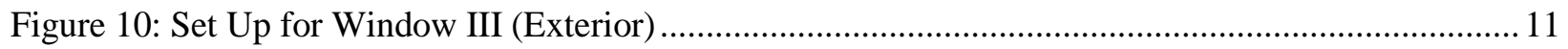

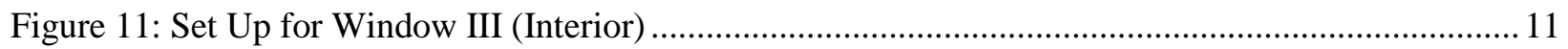

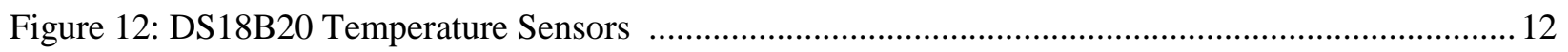

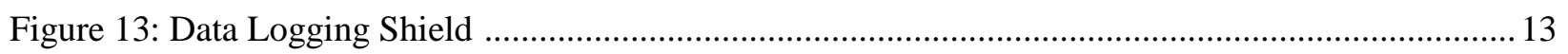

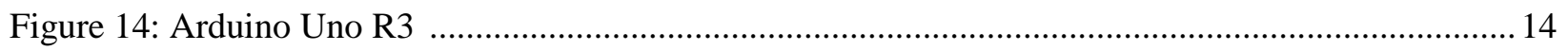

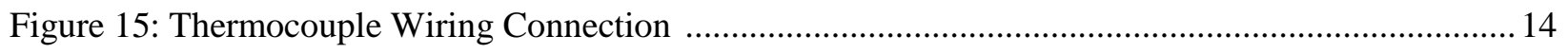

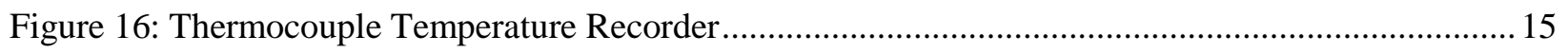

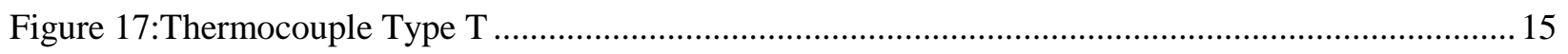

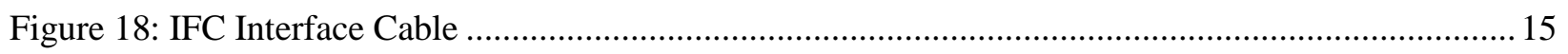

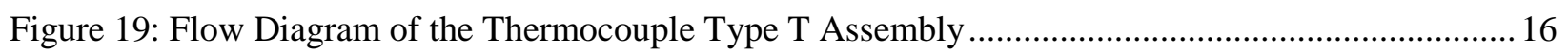

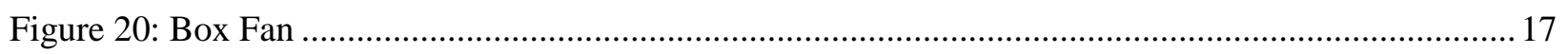

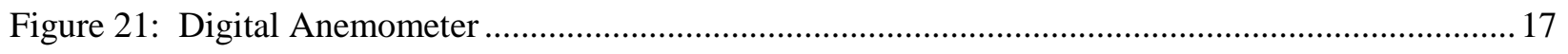

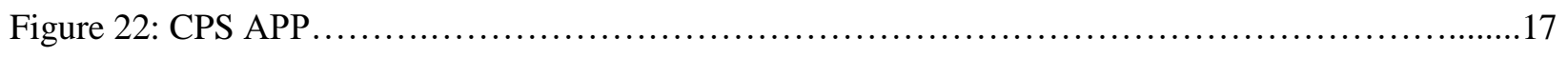

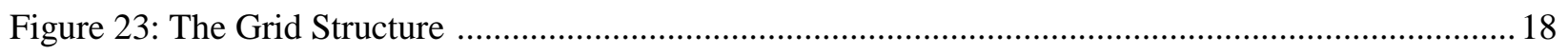

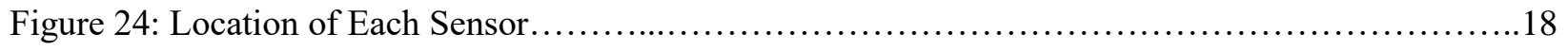

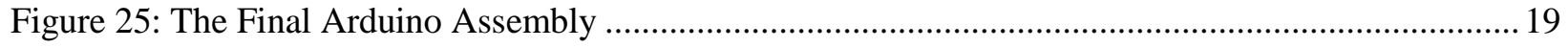

Figure 26: Flow Diagram of DS18B20 Temperature Sensor Assembly .............................................. 19

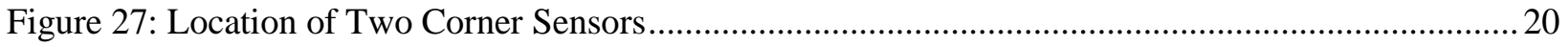

Figure 28: Double Cell and Single Cell Insulated Cellular Shades ......................................................... 35

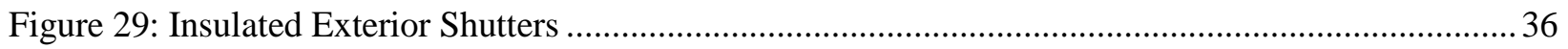




\section{Introduction}

In modern design, architects use large expanses of glazing for aesthetics and simplicity. Application of large window areas continues to develop all over the world, in all climates. Glazing and its structure is the weakest part of a wall system in terms of thermal performance. In cold climates, where the building's exterior temperature varies considerably from the interior, even the best insulated window system cannot resist the heat loss through the building, and it becomes a major heat loss mechanism for the building.

The overall U-value of a window assembly includes surface conductances for exterior and interior air films, which provide some insulation values. The insulation provided by the outside and inside air films is better than the window insulation, since the glazing k-factor is higher than that of the air film $[1,2]$.

Utilizing computational fluid dynamics (CFD) software, a window assembly was modelled in a calm winter scenario as well as windy conditions to measure the impact on the system. It was shown that in windy conditions, the exterior air film is eliminated, reducing the exterior and interior window surface temperature by several degrees. The temperature drop on the exterior surface further weakens the window performance from a heat transfer perspective [3]. The purpose of the current research is to conduct an experimental set up to examine the validity of the CFD results through experimentation and to observe the impact of wind on a window system. 


\section{Literature Review}

Many of the calculation procedures for a window assembly's thermal transmittance is usually estimated under stationary air conditions. Nevertheless, the effect of wind on windows should be considered as well [3].

The overall U-value of a window incorporates surface conductances for both the exterior and interior air films. According to Table 1, the surface conductance for moving air is $34 \mathrm{~W} /(\mathrm{m} 2$. $\mathrm{K}$ ) for winter, $23 \mathrm{~W} /(\mathrm{m} 2 . \mathrm{K})$ for summer, and for still air is $8.3 \mathrm{~W} /(\mathrm{m} 2 . \mathrm{K})[1,2]$.

Table 1: Surface Conductances for Air $(W /(m 2 . K))[1,2]$

\begin{tabular}{|c|c|c|}
\hline Position of surface & Direction of flow & Surface emissivity $(\varepsilon=90)$ \\
\hline Still air (Vertical) & Horizontal & 8.3 \\
\hline Moving air for winter (any position) & any & 34 \\
\hline Moving air for summer (any position) & any & 23 \\
\hline
\end{tabular}

Using computational fluid dynamics, a double-glazed window system was modelled in different conditions [3]. The window in Figure 1 represents the assembly in a calm winter scenario, where the outside and inside temperatures are $-20^{\circ} \mathrm{C}$ and $20^{\circ} \mathrm{C}$, respectively [3]. As indicated in Figure 1, the air film on the outside of the window opening (shown in cyan) maintains the exterior glass temperature at about $-10^{\circ} \mathrm{C}$, which is higher than the outside temperature. 


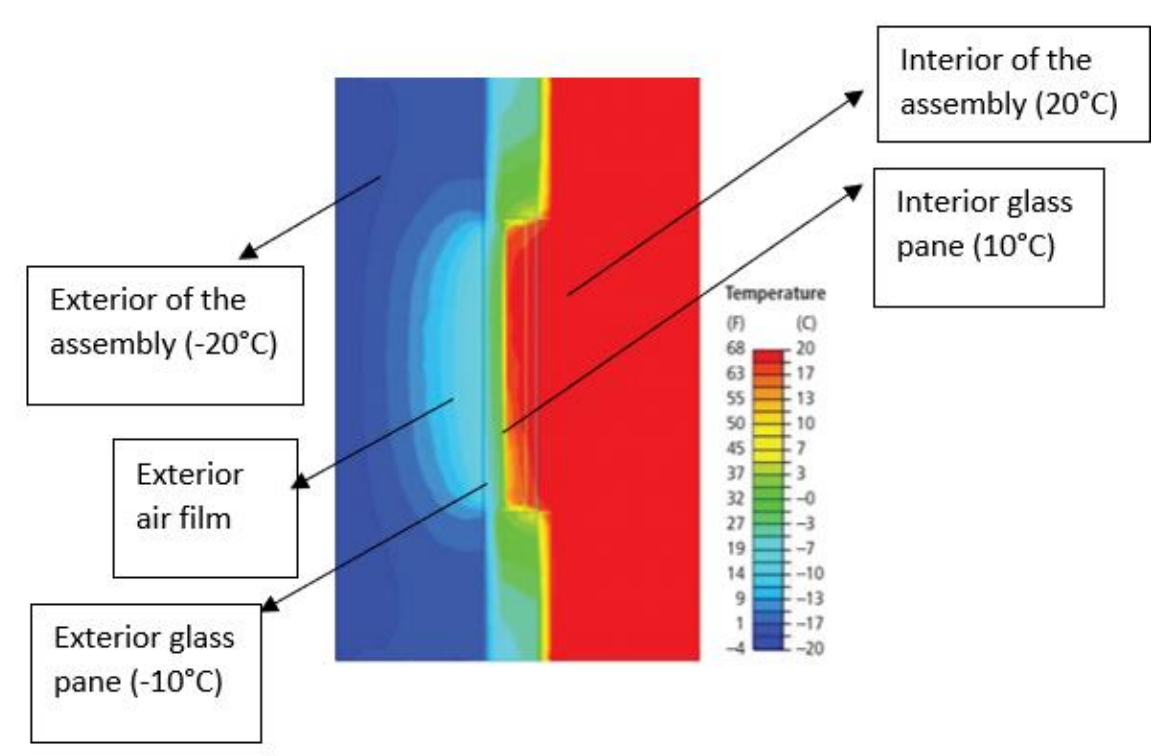

Figure 1: Assembly Temperature with no Wind [3]

The exterior air film constitutes a critical portion of the insulating values of the window assembly, rising the temperature of the interior glass surface, as well. As shown in Figure 1, the exterior air film increases the temperature of the inner pane to a temperature of about $10^{\circ} \mathrm{C}$ and decreases surface heat loss to the outside. Consequently, the exterior surface film is considered a vital portion to a window or any assembly with low thermal resistance.

Figure 2 demonstrates the same assembly under a $10 \mathrm{~m} / \mathrm{s}$ wind, which is directed perpendicular to the glass surface. The wind removes the protective air film on the outside of the glass pane, and ultimately, a great part of the window's insulating factor. As a consequence, the temperature of the exterior glass drops to ambient air temperature, which is $-20^{\circ} \mathrm{C}$. Furthermore, temperature of the interior window pane decreases to $2^{\circ} \mathrm{C}$, increasing the surface heat transfer with the interior. The result is a downward draft toward the inside the room, which can be observed in Figure 2. 


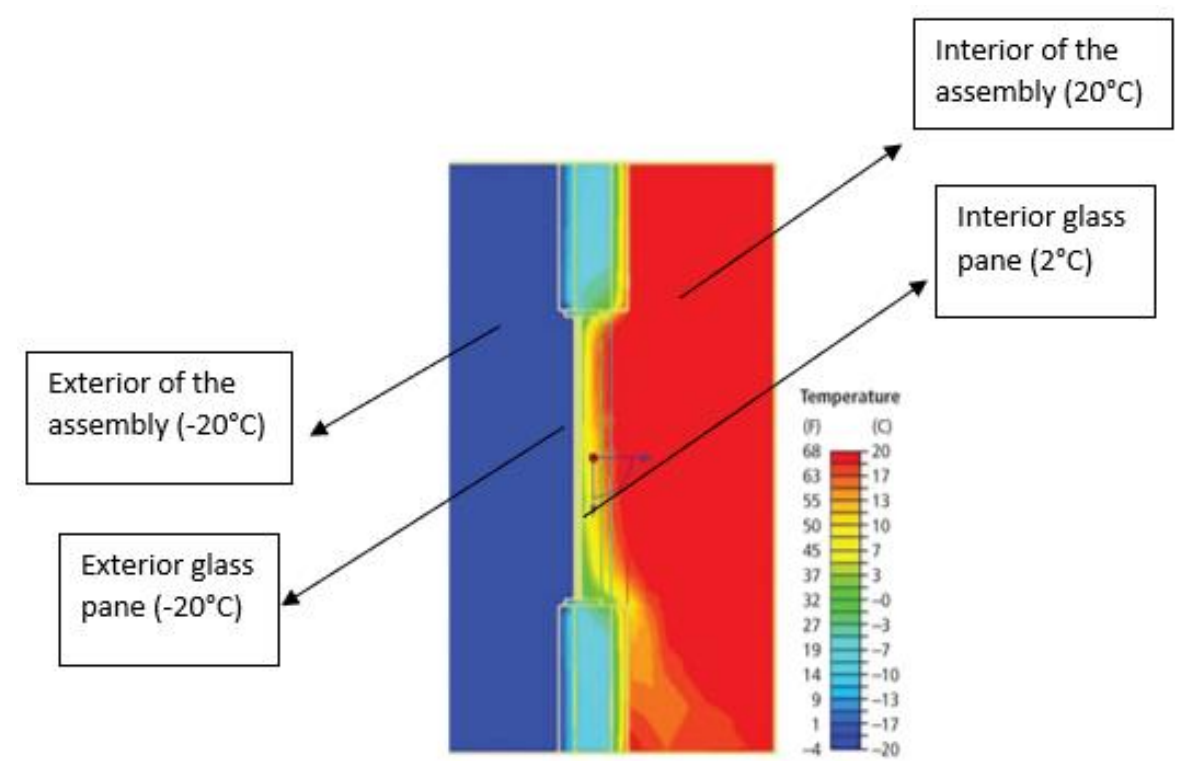

Figure 2: Assembly Temperature with $10 \mathrm{~m} / \mathrm{s}$ Wind [3]

Table 2 further represnets the exterior and interior glass temperature of the window with respect to different wind velocities at $-20^{\circ} \mathrm{C}$. As shown in the table, the temperature of the interior glass pane decreases immediately as the exterior wind velocity increases [3]; for instance, under a $5 \mathrm{~m} / \mathrm{s}$ wind on a $-20^{\circ} \mathrm{C}$ winter day, the temperature of the inetrior glass reduces to $-2.7^{\circ} \mathrm{C}$ compared to $4.6^{\circ} \mathrm{C}$, when there is no extrior wind. As a consequence, the insualting factor of the external air film plays a significant role in a window's thermal performance, particularly, in cold climates. The temperature will eventually stop decreasing, indicating a reverse exponential relationship between temperature and wind velocity [3]. Furthermore, the last column of Table 2 provides the temeprature of the exterior wall plane with respect to different wind velocities at $-20^{\circ} \mathrm{C}$. Results show that the temperature of the exterior wall plane is similar to exterior ambient temperature, and wind has negligible effect on that particular point. 
Table 2: Impact of Different Wind Speed on a Window's Surface Temperature [3]

\begin{tabular}{|c|c|c|c|}
\hline $\begin{array}{c}\text { Wind Velocity } \\
(\mathrm{m} / \mathrm{s})\end{array}$ & $\begin{array}{c}\text { Exterior Glass } \\
\text { Temperature }\left({ }^{\circ} \mathrm{C}\right)\end{array}$ & $\begin{array}{c}\text { Interior Glass } \\
\text { Temperature }\left({ }^{\circ} \mathrm{C}\right)\end{array}$ & Exterior Wall Plane $\left({ }^{\circ} \mathrm{C}\right)$ \\
\hline 0 & -6.7 & 4.6 & -17.6 \\
\hline 1 & -12.2 & 1.9 & -19.24 \\
\hline 2 & -14.7 & -1.3 & -19.63 \\
\hline 5 & -16.9 & -2.7 & -19.85 \\
\hline 7 & -17.6 & -3 & -19.89 \\
\hline 10 & -18.2 & -3.5 & -19.92 \\
\hline
\end{tabular}

The main aim of the current research is to answer the following questions through experimentation:

1) Impact of the exterior air film on the outside surface of a window

2) Impact of the window exterior depth on the glass temperature fluctuations 


\section{Methodology}

The exterior air film on the outside of a window constitutes a significant portion of its insulating values, increasing the exterior surface temperature of the window to a temperature above exterior ambient temperature. The air film also increases the interior glass temperature and reduces the heat transfer from the interior surface. The exterior air film could be affected by different exterior conditions; according to CFD evaluations, even a low wind speed can remove the air film and reduce the exterior and interior surface temperature of the window assembly [3]. The decreased surface temperature increases heat loss from the building's interior, especially in cold climates. The objective is to conduct an experimental procedure to examine the influence of different wind speeds on the air film as well as a window temperature. The experimental procedure included temperature measurements on three different windows, which are described below.

\subsection{Experimental Windows}

Three different windows were selected, so that the exterior sill depth would vary. The windows chosen are all double-glazed with various exterior depths ranging from $2.5 \mathrm{~cm}$ to 11 $\mathrm{cm}$.

\subsubsection{Experimental Window I}

The first window, shown in Figure 3, is located in Richmond hill. The window is a vinylframed double-glazing system. The $1.8 \mathrm{~cm}$ space between the $4 \mathrm{~mm}$ glasses is filled with air. The window dimensions are $65 \mathrm{~cm} \times 105 \mathrm{~cm}$, and the exterior of the interior pane has a coating. The window has an exterior depth of $11 \mathrm{~cm}$. 

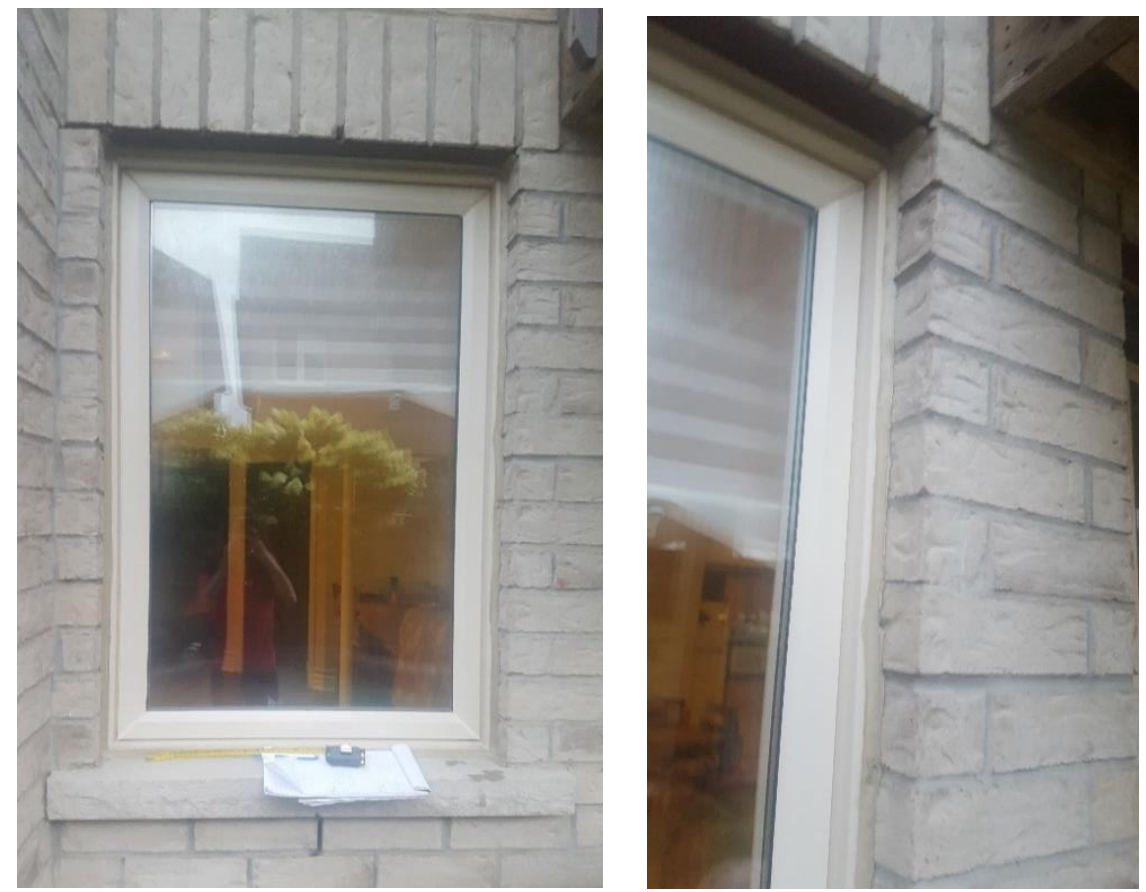

\section{Figure 3: Window I}

\subsubsection{Experimental Window II}

The second window, shown in Figure 4, is located in downtown, Toronto. The window is an aluminium-framed double-glazing system. The $1.3 \mathrm{~cm}$ space between the $6 \mathrm{~mm}$ glasses is filled with air. The window dimensions are $139 \mathrm{~cm} \times 113 \mathrm{~cm}$, and the exterior of the interior pane has a coating. The window has an exterior depth of $2.5 \mathrm{~cm}$.
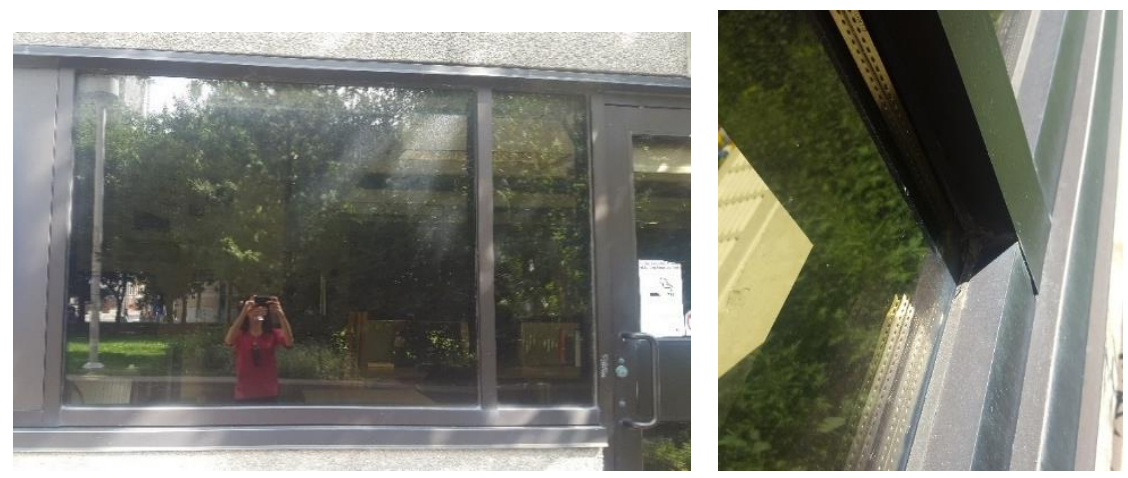

Figure 4: Window II 


\subsubsection{Experimental Window III}

The third window, shown in Figure 5, is located in Richmond hill. The window is a vinyl-framed double-glazing system. The $2 \mathrm{~cm}$ space between the $4 \mathrm{~mm}$ glasses is filled with air. The window dimensions are $80 \mathrm{~cm} \times 43 \mathrm{~cm}$, and the exterior of the interior pane has a coating. The window has an exterior depth of $11 \mathrm{~cm}$.
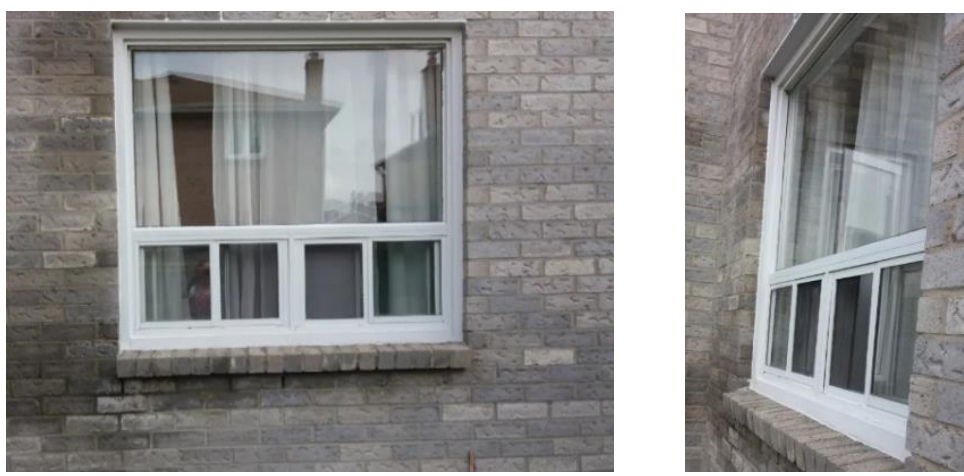

Figure 5: Window III

\subsection{Experimental Set Up}

Two exterior grids and one interior grid were constructed for each window based on the available dimensions. The first exterior grid structure was located within the exterior depth of the window, while the second structure was located $1 \mathrm{~m}$ from the window pane. There was only one interior grid, which was located $50 \mathrm{~cm}$ from the window pane.

Thirty-five sensors were used to measure the temperature of the window assemblies. Seven waterproof DS18B20 digital temperature sensors were mounted on each planar grid. Seven thermocouple type $\mathrm{T}$ were also attached to the external and internal window glasses to measure the temperature fluctuations on the glass surface. Due to negligible exterior wind flow, a box fan with three different speeds was utilized to create artificial wind effect. The fan was located $40 \mathrm{~cm}$ from the window glass, between the two exterior grids, to produce different air 
flows. It was run at different speeds $(0 \mathrm{~m} / \mathrm{s}, 1.93 \mathrm{~m} / \mathrm{s}$, and $3 \mathrm{~m} / \mathrm{s})$ for 15 minutes, and the temperature was recorded every minute. The procedure was repeated for different angles $\left(45^{\circ}\right.$, $90^{\circ}, 135^{\circ}$, and $180^{\circ}$ ) to analyze the impact of flow direction on the window, as well. The experimental set up for all the windows are provided in Figures 6 through 11.
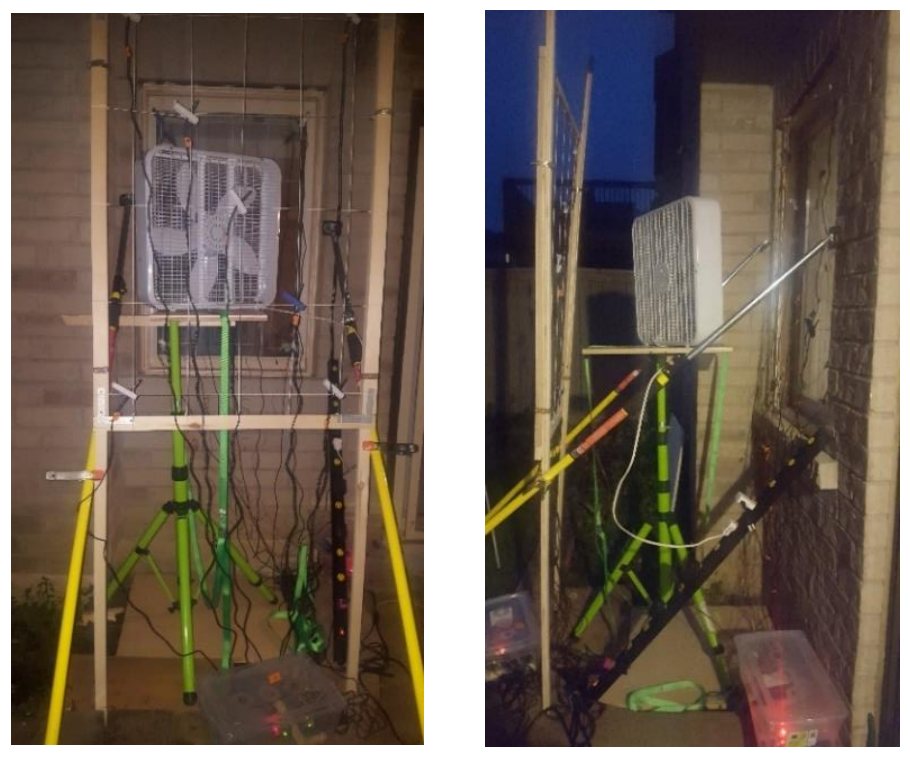

Figure 6: Set Up for Window I (Exterior)

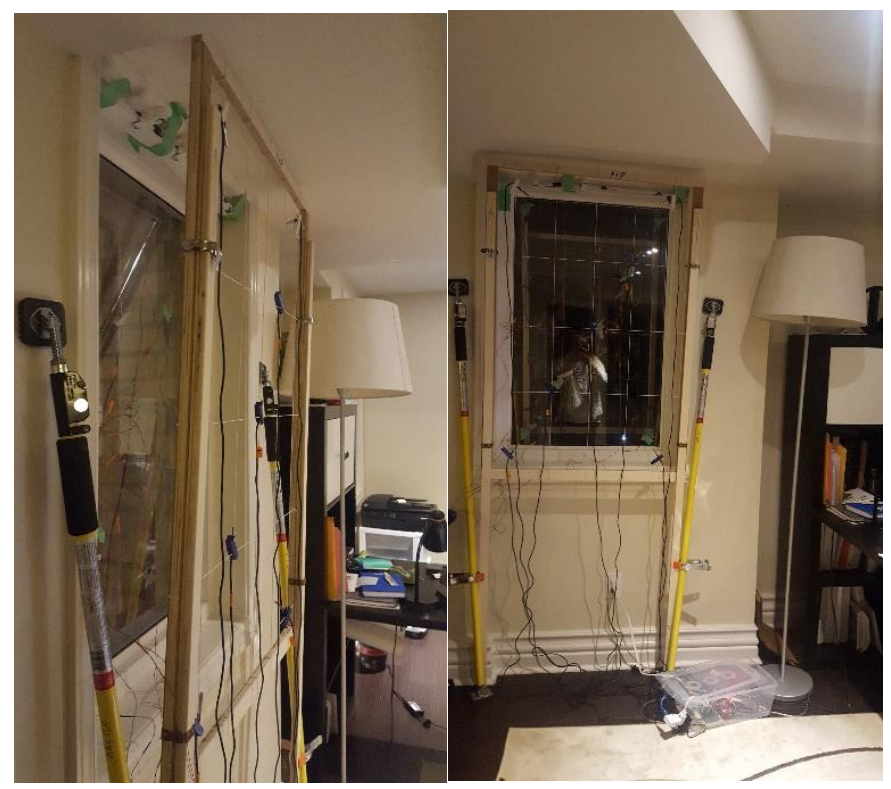

Figure 7: Set Up for Window I (Interior) 

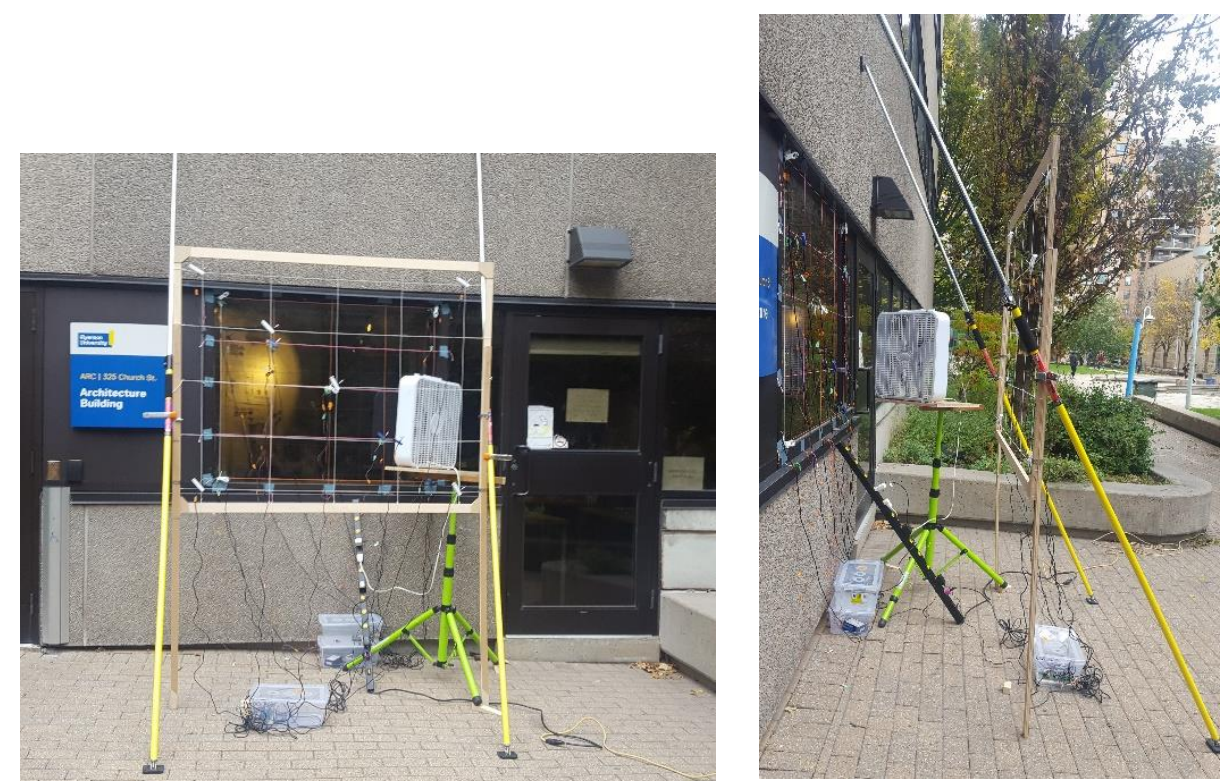

Figure 8: Set Up for Window II (Exterior)

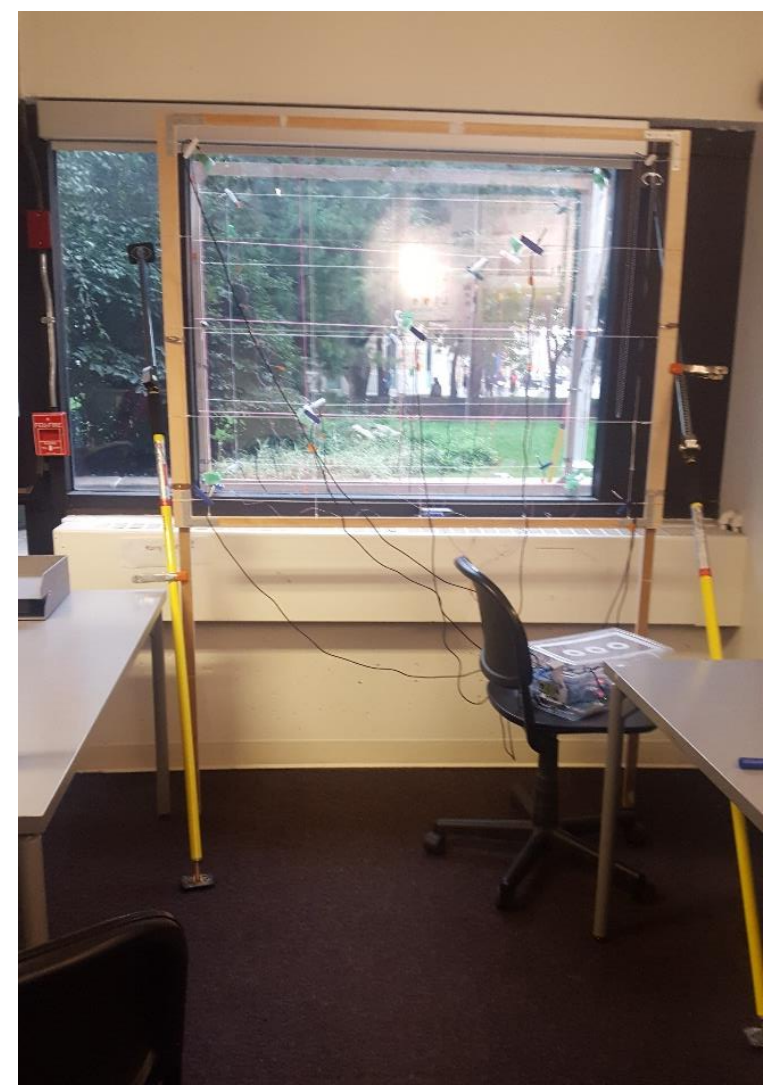

Figure 9: Set Up for Window II (Interior) 

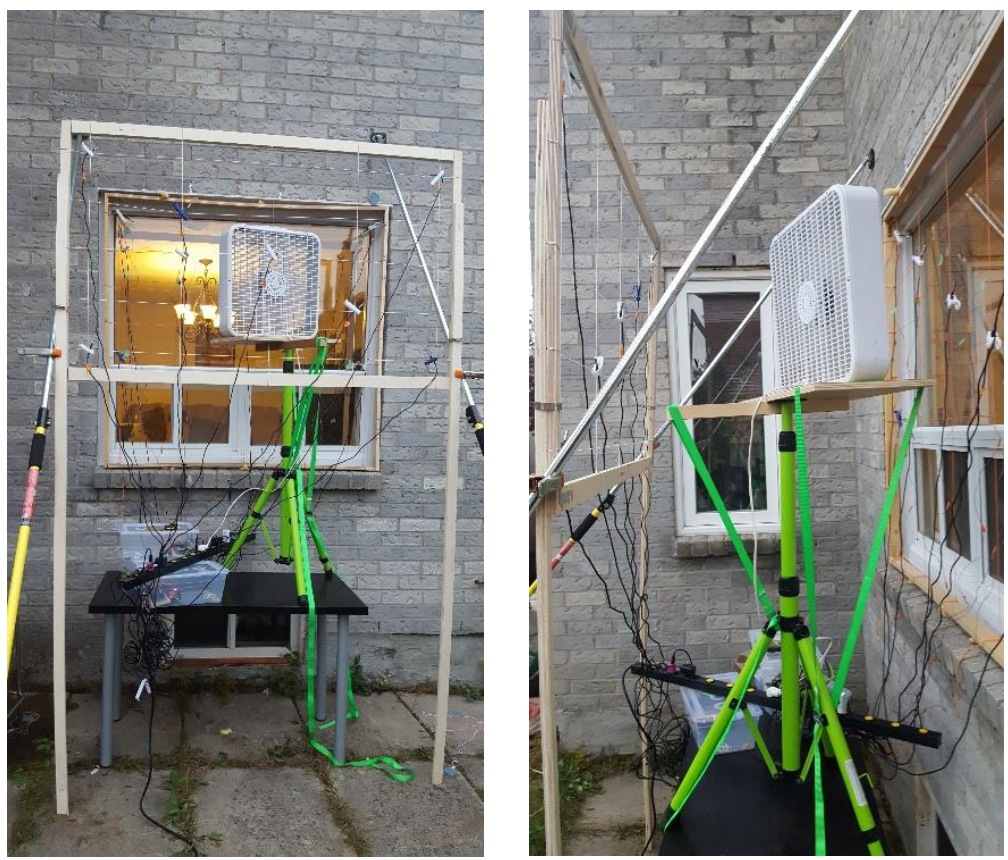

Figure 10: Set Up for Window III (Exterior)
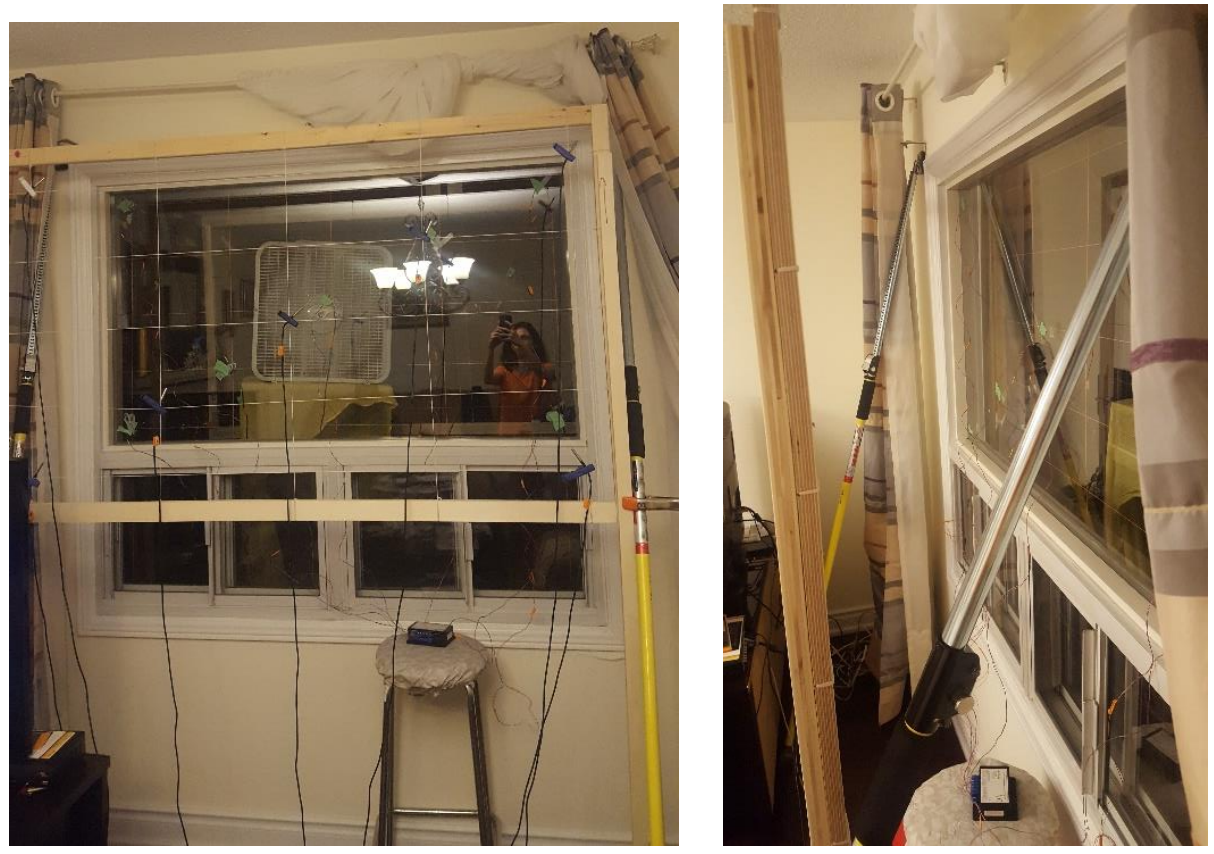

Figure 11: Set Up for Window III (Interior) 


\subsection{Instrumentation}

The following instrumentation set is used for experimental measurement.

\subsubsection{Waterproof DS18B20 Digital Temperature Sensors}

Twenty-one DS18B20 temperature sensors were used in total; seven sensors were put on each of the exterior grids (14 sensors outside), and seven sensors were put on the interior grid. DS18B20 Digital Temperature Sensors (Figure 12) can be used to measure the temperature in wet conditions and can be used in the temperature range of -55 to $125^{\circ} \mathrm{C}$ [4]. Since each DS18B20 temperature sensor possesses an exclusive silicon serial number to differentiate it from other sensors, multiple sensors can be used on the same 1-wire bus utilizing a single digital pin. They are also relatively precise with the accuracy of $\pm 0.5^{\circ} \mathrm{C}$ over much of the range [4]. They are used with Arduino [6] to read and record the temperature measurements. Each sensor has a red wire, which connects to the VCC (5V or positive) of Arduino, a yellow wire, which connects to the data pin (2-13), and a black wire, which connects to the ground (negative) of Arduino.

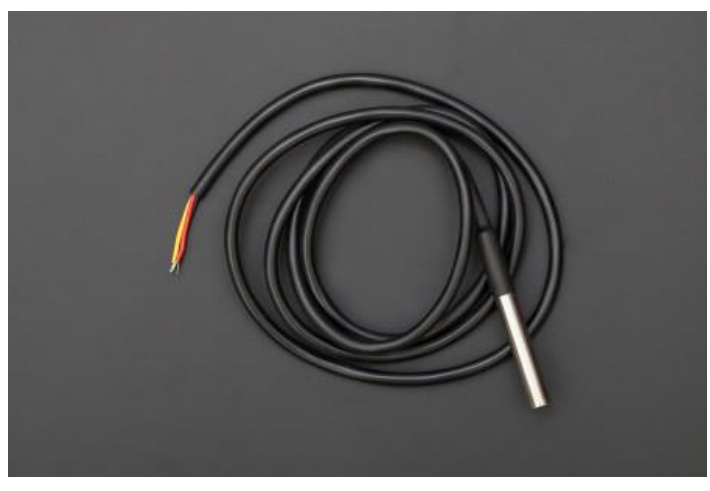

Figure 12: DS18B20 Temperature Sensors [4] 


\subsubsection{Data Logging Shield for Arduino UNO, Assembled, R3 Compatible}

The assembled data logging shield for Arduino (Figure 13) includes a SD card slot and DS1307Z Real Time Clock, so that the user can save all data along with the timestamps to files on any FAT16 or FAT 32 formatted SD card. Therefore, the saved data is ready to be read by any spreadsheet, plotting, or any other analysis program [5].
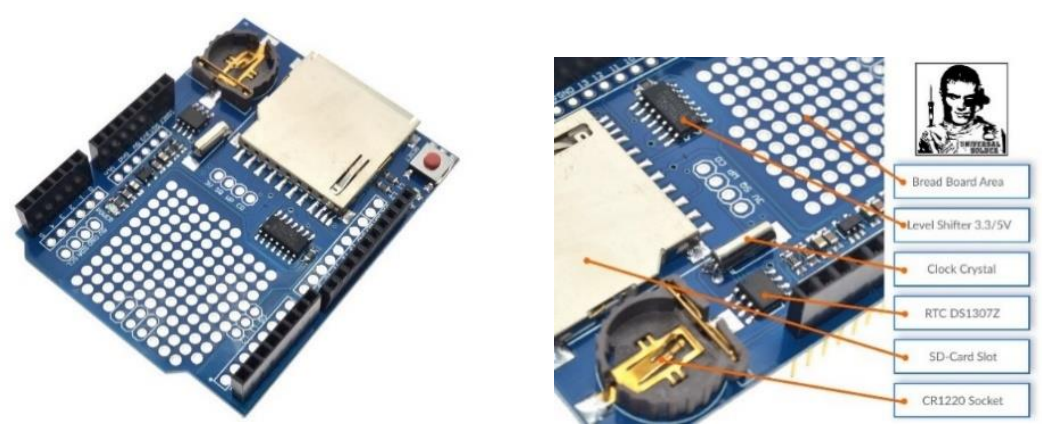

Figure 13: Data Logging Shield [5]

\subsubsection{Elegoo UNO R3 Board ATmega328P ATMEGA16U2 with USB Cable [for Arduino]}

Arduino is an open-source physical computation platform based on an uncomplicated input/output board. In addition, it is a development environment that applies the processing/ wiring language. Arduino could be utilized to develop "stand-alone interactive objects or could be connected to software on a computer" [6]. The Elegoo Uno R3 (Figure 14) was programmed, so that the readings from seven DS18B20 temperature sensors would be recorded on the memory card along with the timestamps. The code for measuring and recording the temperatures could be found in appendix A. 

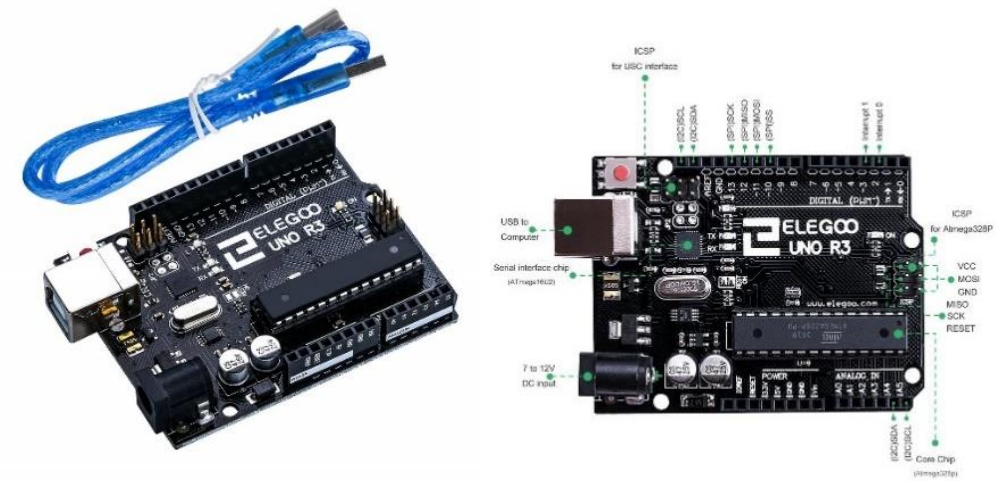

Figure 14: Arduino Uno R3 [6]

\subsubsection{Thermocouple Type $T$}

A total of fourteen thermocouple type $\mathrm{T}$ were used, from which seven were attached to the exterior glass surface, and seven were attached to the interior glass surface. There are 2 wires attached to each thermocouple type T, as shown in Figure 15. The blue wire is connected to the positive side (Copper), and the red wire is connected to the negative side (Constantan). The type $\mathrm{T}$ can measure temperatures in the range of $-270^{\circ} \mathrm{C}-370^{\circ} \mathrm{C}[8]$.
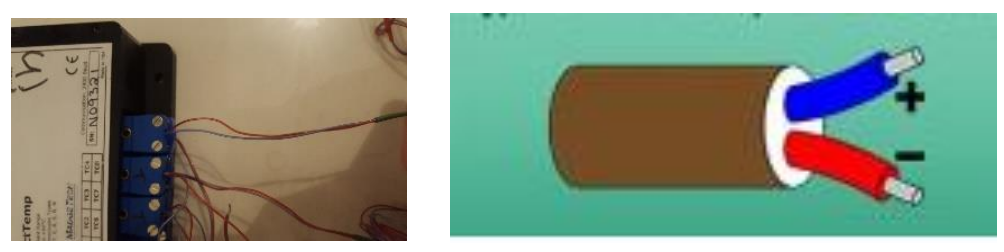

Figure 15: Thermocouple Wiring Connection [8]

\subsubsection{An Eight-Channel Thermocouple Temperature Recorder (OctTemp)}

The OctTemp (Figure 16) is an "eight channel, battery powered, stand alone thermocouple recorder" [21]. It is compatible with thermocouple types J,B,N,E,R,S,K,and T. In the research project thermocouple type T (Figure 17) was connected to the OctTemp data logger. Each channel can measure and record up to 14,563 readings. The OctTemp is connected to a computer via MadgeTech's IFC200 interface cable (Figure 18), which communicates between 
the stand-alone data logger and the MadgeTech software. Through the interface cable, data logger is started, stopped, or downloaded. The OctTemp is connected to a computer via IFC200 interface cable to set the start time and recording intervals through MadgeTech software. After recording temperature readings along with their time stamps, the data logger is connected to the computer via IFC200 cable to download the data. The "storage medium is non-volatile solidstate memory" [7], which allows for the maximal information security even if the battery gets discharged [7]. Figure 19 shows the connection of thermocouple T from window to the data logger. The data logger is then connected to the computer through IFC200 interface cable to download the data.

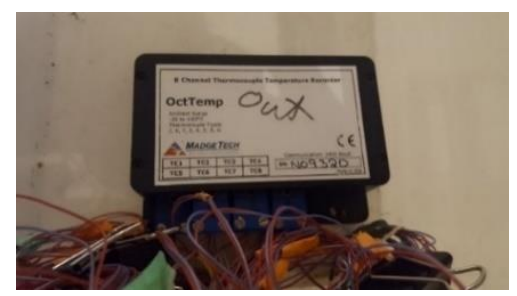

Figure 16: Thermocouple Temperature Recorder

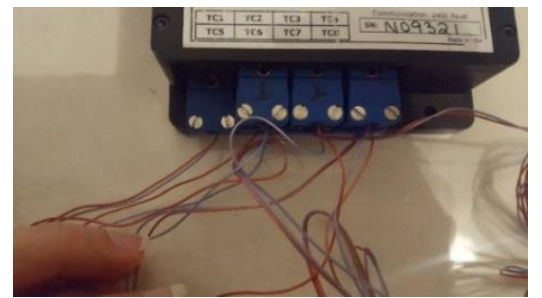

Figure 17:Thermocouple Type T

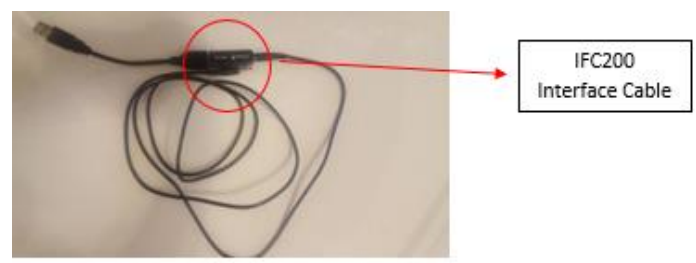

Figure 18: IFC Interface Cable 


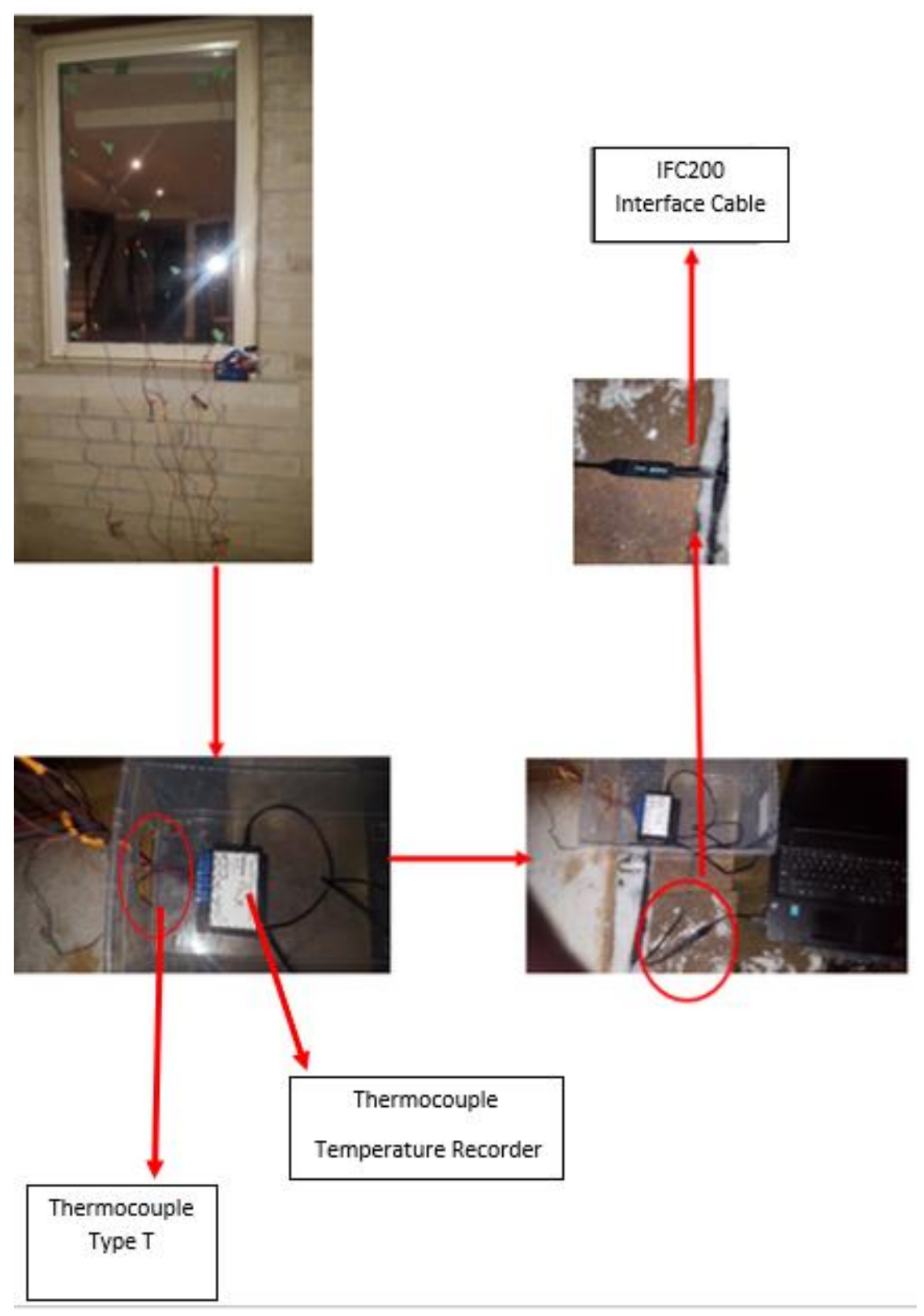

Figure 19: Flow Diagram of the Thermocouple Type T Assembly 


\subsubsection{Fan}

Exterior wind flow was negligible during the measurements, and hence, a 20-inch box fan (Figure 20) was used to create artificial wind flows. The fan is set at three different speeds ( 0 $\mathrm{m} / \mathrm{s}, 1.9 \mathrm{~m} / \mathrm{s}$, and $3 \mathrm{~m} / \mathrm{s})$ and four different angles $\left(45^{\circ}, 90^{\circ}, 135^{\circ}\right.$, and $\left.180^{\circ}\right)$ to induce artificial air flows.

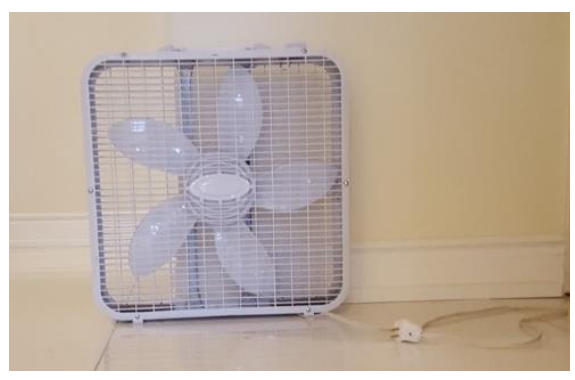

Figure 20: Box Fan

\subsubsection{Digital Anemometer}

Digital anemometer (Figure 21) works like a pitot tube, with which the airflow velocity could be measured. It includes Bluetooth Smart technology, so that it works wirelessly with smartphones. CPS Link could be downloaded on smartphones, and by moving the anemometer around the fan, the airflow readings are shown in $\mathrm{m} / \mathrm{s}$ (Figure 22) [9].

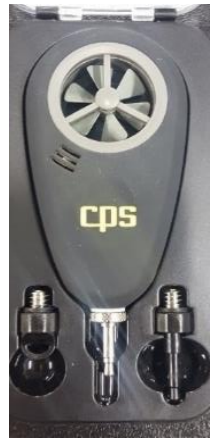

Figure 21: Digital Anemometer

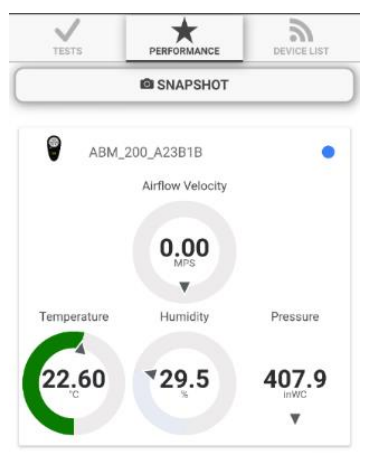

Figure 22: CPS APP [9] 


\subsection{Grid Structure}

Three grid structures were provided for each window based on the available dimensions (Figure 23). The outer frame of grids is made of plywood, while the grid itself is made of thin strings, so they do not interrupt airflow. The location of sensors on each grid is shown in Figure 24.

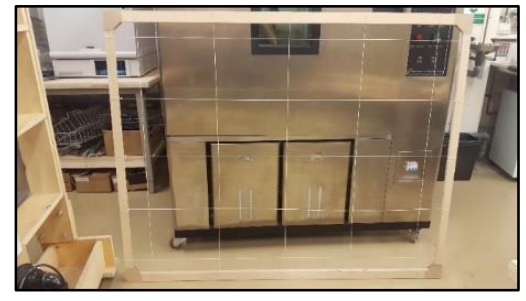

Figure 23: The Grid Structure

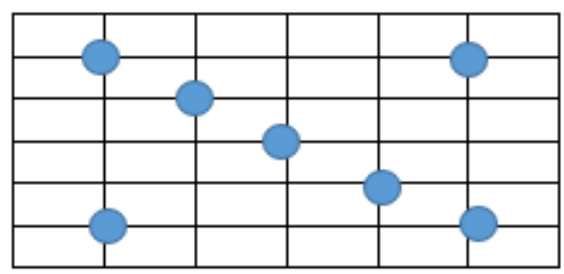

Figure 24: Location of Each Sensor

\subsection{DS18B20 Temperature Sensor Assembly}

Figure 25 shows the final DS18B20 temperature sensor assembly. A total of 21 temperature sensors were used, from which 14 were placed outside ( 7 for each of the exterior grids), and 7 inside the room.There are 3 boxes, each of which incoporates an Arduino UNO R3 with the data logging shield on top of it. Each of them also has seven DS18B20 temperature sensors, and they are all soldered to a PCB board (the green board) to create a permanent connection. There is also a $5 \mathrm{~V}$ Breadboard voltage regulator on the PCB board to provide $5 \mathrm{~V}$ voltage for seven sensors.

Figure 26 further shows the final grid strcuture assembly, where the sensors connected to arduino are mounted on the grid structure. After the experiment, the ardunio is connected to the computer via a USB port to download the data. 


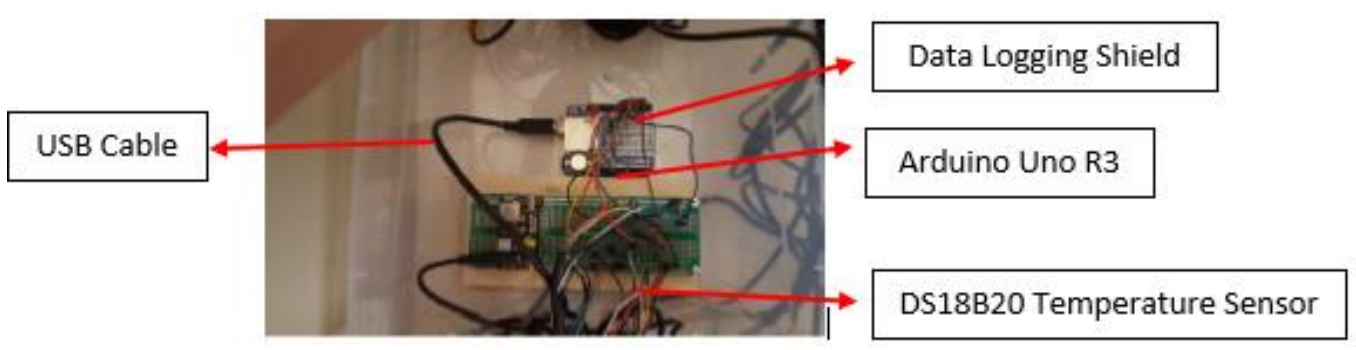

Figure 25: The Final Arduino Assembly

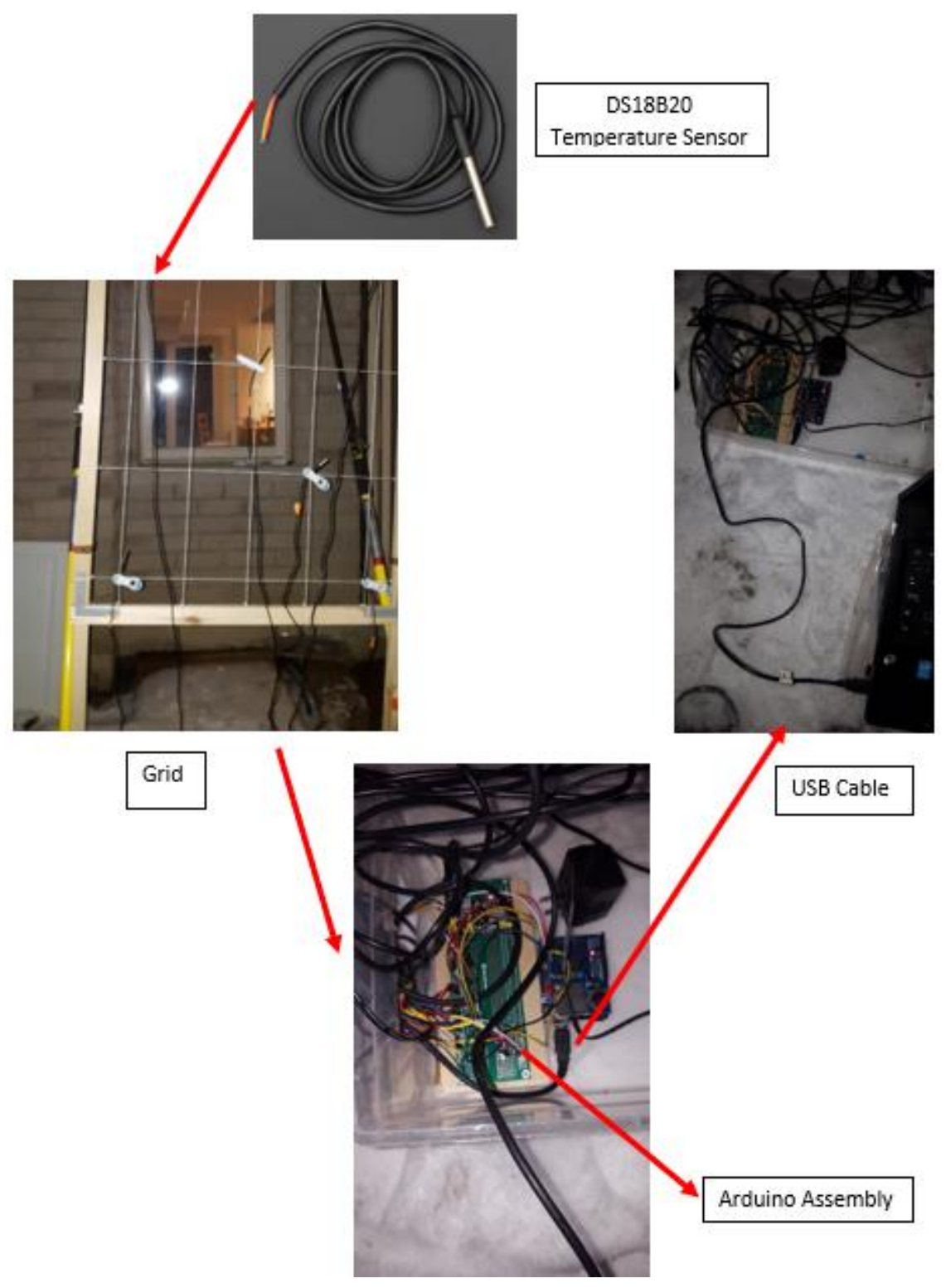

Figure 26: Flow Diagram of DS18B20 Temperature Sensor Assembly 


\section{Measurement Results and Discussions}

An experiment was conducted on three windows to examine the impact of different air flows on the assemblies' temperature. Seven sensors were attached to the glass surface both inside and outside along with seven sensors on the interior and exterior grids. Due to minimal amount of wind outside, a fan was used to induce artificial air flow. The fan between the two exterior grids was set at four different angles $\left(45^{\circ}, 90^{\circ}, 135^{\circ}\right.$, and $\left.180^{\circ}\right)$, and it was further set at different speeds, at each angle. The duration of each measurement was 15 minutes with the temperature being recorded every minute. The collected data was analyzed by calculating the average of all seven sensors on each surface, per minute. Then, the average temperatures calculated for each minute were further averaged to calculate the average temperature during each 15 minutes. Average temperature results were further compared with sensor 1 and sensor 2 temperatures (Figure 27) to see if the average results differ from that of sensors 1 and 2.

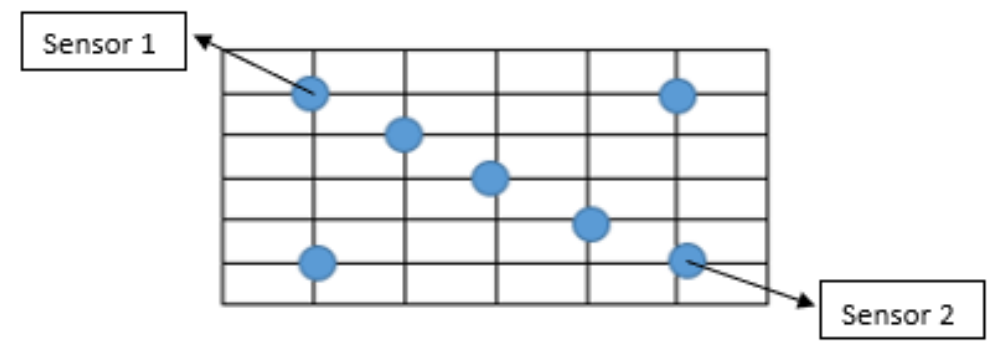

Figure 27: Location of Two Corner Sensors 


\subsection{Window I}

The experiment at the first window location was performed on two different occasions; The first one was performed on October $18^{\text {th }}, 2018$ between 2 to $6 \mathrm{am}$, where the exterior and interior ambient temperatures were recorded to be around $4.6^{\circ} \mathrm{C}$ and $19^{\circ} \mathrm{C}$, respectively. The second one was performed on November $15^{\text {th }}, 2018$ between 1 to $5 \mathrm{am}$, where the exterior and interior ambient temperatures were recorded to be around $-7^{\circ} \mathrm{C}$ and $20^{\circ} \mathrm{C}$, respectively.

The window is a double-glazed vinyl window, with an exterior depth of $11 \mathrm{~cm}$. Seven sensors were attached to the interior and exterior window surface along with seven sensors on the internal and external grid structures. The fan was set at different angles and speeds for 15 minutes, and the temperature was recorded every minute. The collected data was analyzed by taking the average of all seven sensors on each grid, per minute. The average temperature results obtained per minute were further averaged during each 15 minutes. Average temperatures were also compared with sensor 1 and sensor 2 temperatures to see if the average results were different from that of individual sensor. Table 3 shows the first set of average results, which were obtained on October $18^{\text {th }}, 2018$. 


\subsection{1: Set I Results (October $18^{\text {th }}, 2018$ )}

Table 3: Window I Temperature Results (Positive Temperature)

\begin{tabular}{|c|c|c|c|c|c|c|}
\hline Angle & Flow(m/s) & $\begin{array}{c}\text { Exterior Grid } \\
\text { within the } \\
\text { depth }\left({ }^{\circ} \mathrm{C}\right)\end{array}$ & $\begin{array}{c}\text { Exterior grid } 1 \mathrm{~m} \\
\text { from the window } \\
\left({ }^{\circ} \mathrm{C}\right)\end{array}$ & $\begin{array}{c}\text { Interior grid } \\
\left({ }^{\circ} \mathrm{C}\right)\end{array}$ & $\begin{array}{c}\text { Interior Glass } \\
\text { Surface }\left({ }^{\circ} \mathrm{C}\right)\end{array}$ & $\begin{array}{c}\text { Exterior Glass } \\
\text { Surface }\left({ }^{\circ} \mathrm{C}\right)\end{array}$ \\
\hline \multirow{3}{*}{$45^{\circ}$} & 0 & 4.98 & 4.86 & 19.88 & 15.85 & 6.38 \\
\cline { 2 - 7 } & 1.9 & 4.85 & 4.71 & 20.02 & 16.04 & 5.91 \\
\cline { 2 - 7 } & 3 & 4.84 & 4.68 & 19.96 & 15.92 & 5.55 \\
\hline \multirow{3}{*}{$90^{\circ}$} & 0 & 4.73 & 4.58 & 19.85 & 15.96 & 6.38 \\
\cline { 2 - 7 } & 1.9 & 4.74 & 4.60 & 19.75 & 15.91 & 5.70 \\
\hline \multirow{3}{*}{$135^{\circ}$} & 3 & 4.73 & 4.57 & 19.71 & 15.77 & 5.36 \\
\cline { 2 - 7 } & 1.9 & 4.83 & 4.64 & 19.66 & 15.89 & 6.33 \\
\cline { 2 - 7 } & 3 & 4.74 & 4.62 & 19.72 & 15.95 & 5.82 \\
\hline \multirow{3}{*}{$180^{\circ}$} & 0 & 4.53 & 4.62 & 19.63 & 15.88 & 5.49 \\
\cline { 2 - 7 } & 1.9 & 4.26 & 4.31 & 19.33 & 15.63 & 6.25 \\
\cline { 2 - 7 } & 3 & 4.23 & 4.08 & 19.28 & 15.66 & 6.08 \\
\hline
\end{tabular}

In the first scenario, where the fan was set at 45-degree angle, the primary exterior surface temperature was $6.38^{\circ} \mathrm{C}$. Increasing the flow to $1.9 \mathrm{~m} / \mathrm{s}$ decreased the temperature by almost half a degree Celsius, and increasing the flow to $3 \mathrm{~m} / \mathrm{s}$ further decreased it by $0.36^{\circ} \mathrm{C}$. Therefore, increasing the flow from 0 to $3 \mathrm{~m} / \mathrm{s}$ caused the temperature of the exterior glass to reduce by $0.83^{\circ} \mathrm{C}$. In addition, temperature change on the interior surface is negligible.

Likewise, when the fan was at 90-degree or 135-degree angle, increasing the flow from 0 to 3 $\mathrm{m} / \mathrm{s}$ caused a temperature drop of almost $1^{\circ} \mathrm{C}$ on the exterior glass, while the temperature of the inside surface remained constant. On the other hand, the last set of results showed that when the fan was at 180-degree angle, the air flow has a negligible effect on the exterior and interior glass surface. Moreover, the flow does not affect the temperature readings of the sensors within the exterior depth regardless of the angle. 
Table 4 shows the temperature for sensors 1 and 2 during each 15 minutes. When the fan was at 45 degree, increasing the flow to $3 \mathrm{~m} / \mathrm{s}$ reduced the temperature of sensor 1 by $1.4^{\circ} \mathrm{C}$, and sensor 2 by $0.6^{\circ} \mathrm{C}$. In addition, changing the angle to 90 degree resulted in $1.8^{\circ} \mathrm{C}$ reduction in sensor 1 temperature and $0.8^{\circ} \mathrm{C}$ reduction in sensor 2 temperature. Lastly, at 135 degree, the temperature decrease in sensors 1 and 2 was $1.1^{\circ} \mathrm{C}$ and $0.6^{\circ} \mathrm{C}$, respectively. Comparing the results with average results suggests that the temperature drop in each individual sensor is slightly different from the average results. To delve into analysis deeply, the temperature drop of each sensor might be greater or lower than the average depending on its location. For example, sensor 1 showed a temperature reduction of $1.1^{\circ} \mathrm{C}-1.8^{\circ} \mathrm{C}$, which is greater than the average result; However, the interior glass surface still maintained a consistent temperature due to minor effects on the outside glass. Moreover, when the fan was set at $180^{\circ}$, the surface temperature was constant, which indicates that the flow parallel to the window surface does not affect its temperature.

Table 4: Positive Temperature Data for Corner Sensors (Window I)

\begin{tabular}{|c|c|c|c|c|c|c|c|}
\hline & & \multicolumn{2}{|c|}{ Exterior Depth $\left({ }^{\circ} \mathrm{C}\right)$} & \multicolumn{2}{c|}{ Exterior Surface $\left({ }^{\circ} \mathrm{C}\right)$} & \multicolumn{2}{c|}{ Interior Surface $\left({ }^{\circ} \mathrm{C}\right)$} \\
\hline \multirow{3}{*}{ Angle } & $\begin{array}{c}\text { Flow } \\
(\mathrm{m} / \mathrm{s})\end{array}$ & 1 & 2 & 1 & 2 & 1 & 2 \\
\hline \multirow{3}{*}{$45^{\circ}$} & 0 & 4.7 & 5.0 & 7.5 & 5.9 & 16.1 & 15.1 \\
\cline { 2 - 8 } & 1.9 & 4.6 & 4.9 & 6.7 & 5.7 & 16.3 & 15.3 \\
\cline { 2 - 8 } & 3 & 4.6 & 4.8 & 6.1 & 5.3 & 16.2 & 15.3 \\
\hline \multirow{3}{*}{$90^{\circ}$} & 0 & 4.5 & 4.8 & 7.4 & 6.0 & 16.2 & 15.3 \\
\cline { 2 - 8 } & 1.9 & 4.4 & 4.7 & 6.2 & 5.5 & 16.1 & 15.3 \\
\cline { 2 - 8 } & 3 & 4.4 & 4.7 & 5.6 & 5.2 & 16.0 & 15.1 \\
\hline \multirow{3}{*}{$135^{\circ}$} & 0 & 4.6 & 4.9 & 7.3 & 6.1 & 16.0 & 15.2 \\
\cline { 2 - 8 } & 1.9 & 4.5 & 4.9 & 6.8 & 5.8 & 16.1 & 15.3 \\
\cline { 2 - 8 } & 3 & 4.4 & 4.8 & 6.2 & 5.5 & 16.0 & 15.1 \\
\hline \multirow{3}{*}{$180^{\circ}$} & 0 & 4.3 & 4.5 & 7.4 & 5.9 & 15.8 & 15.0 \\
\cline { 2 - 8 } & 1.9 & 4.1 & 4.2 & 7.2 & 5.7 & 15.8 & 15.0 \\
\cline { 2 - 8 } & 3 & 4.0 & 4.2 & 7.1 & 5.5 & 15.9 & 14.9 \\
\hline
\end{tabular}




\subsection{2: Set II Results (November 15th, 2018)}

The second test was performed on November 15th, 2018 between 1 to 5 am, where the outside temperature was recorded to be around $-7^{\circ} \mathrm{C}$. The results are shown in Table 5 . According to the table, temperature drop on the exterior surface of the window is even more when the ambient temperature is negative. For example, when the fan was set at an angle of $45^{\circ}$, the temperature on the exterior glass surface decreased from $-1.21^{\circ} \mathrm{C}$ to $-5.23^{\circ} \mathrm{C}\left(4.02^{\circ} \mathrm{C}\right.$ temperature decrease), which caused a temperature drop of $0.84^{\circ} \mathrm{C}$ on the inside. Results from 90-degree angle also provide that increasing the air flow from 0 to $3 \mathrm{~m} / \mathrm{s}$ reduced the temperature on the exterior glass by $3.88^{\circ} \mathrm{C}$ and on the interior glass by $0.69^{\circ} \mathrm{C}$. In addition, when the fan was set at 135 degree, the temperature drop on the external surface was $4.07^{\circ} \mathrm{C}$ and on the internal surface was $0.89^{\circ} \mathrm{C}$. When the fan was set at 180 degree, the temperature change on the window surface was minor, which, again, suggests that a wind flow parallel to the glass, has a minor effect on its temperature. Also, the air flow has no effect on the sensors within the exterior depth, as they show an almost consistent temperature. 
Table 5: Window I Temperature Results (Negative Temperature)

\begin{tabular}{|c|c|c|c|c|c|c|}
\hline Angle & Flow $(\mathrm{m} / \mathrm{s})$ & $\begin{array}{c}\text { Exterior Grid } \\
\text { within the } \\
\text { depth }\left({ }^{\circ} \mathrm{C}\right)\end{array}$ & $\begin{array}{c}\text { Exterior grid } 1 \mathrm{~m} \\
\text { from the window } \\
\left({ }^{\circ} \mathrm{C}\right)\end{array}$ & $\begin{array}{c}\text { Interior grid } \\
\left({ }^{\circ} \mathrm{C}\right)\end{array}$ & $\begin{array}{c}\text { Interior Glass } \\
\text { Surface }\left({ }^{\circ} \mathrm{C}\right)\end{array}$ & $\begin{array}{c}\text { Exterior Glass } \\
\text { Surface }\left({ }^{\circ} \mathrm{C}\right)\end{array}$ \\
\hline \multirow{4}{*}{$45^{\circ}$} & 0 & -6.45 & -6.70 & 20.12 & 14.29 & -1.21 \\
\cline { 2 - 7 } & 1.9 & -6.43 & -6.69 & 20.17 & 14.02 & -3.92 \\
\cline { 2 - 7 } & 3 & -6.67 & -6.78 & 20.11 & 13.45 & -5.23 \\
\hline \multirow{3}{*}{$90^{\circ}$} & 0 & -6.06 & -6.86 & 20.18 & 13.85 & -2.11 \\
\cline { 2 - 7 } & 1.9 & -6.56 & -6.73 & 20.30 & 13.69 & -4.76 \\
\hline \multirow{3}{*}{$135^{\circ}$} & 3 & -6.71 & -6.77 & 20.17 & 13.16 & -5.99 \\
\cline { 2 - 7 } & 0 & -6.18 & -6.94 & 19.97 & 13.66 & -2.36 \\
\cline { 2 - 7 } & 1.9 & -6.38 & -6.55 & 19.95 & 13.34 & -4.11 \\
\hline \multirow{3}{*}{$180^{\circ}$} & 3 & -6.24 & -6.32 & 20.05 & 12.77 & -6.43 \\
\cline { 2 - 7 } & 1.9 & -6.24 & -6.05 & 20.03 & 13.82 & -1.62 \\
\cline { 2 - 7 } & 3 & -6.24 & -6.05 & 20.17 & 14.05 & -1.70 \\
\hline
\end{tabular}

Table 6 also provides the temperature data for the two corner sensors. According to the data provided, the temperature drop of sensor 2 is less than average results; however, when the fan was set at 90 degree, the temperature of sensor 1 decreased by $4.3^{\circ} \mathrm{C}$ on the outside, and by $1.4^{\circ} \mathrm{C}$ on the inside, which is greater than the average results. In the case of 45 degree or 135 degree, sensor 1 temperature dropped by almost $4^{\circ} \mathrm{C}$ on the outside, and by $1^{\circ} \mathrm{C}$ on the inside, which is almost the same as average results. The temperature drop when the fan was at 180 degree is negligible, and thus, neglected. 
Table 6: Negative Temperature Data for Corner Sensors (Window I)

\begin{tabular}{|c|c|c|c|c|c|c|c|}
\hline \multicolumn{2}{|c|}{} & \multicolumn{2}{|c|}{ Exterior depth $\left({ }^{\circ} \mathrm{C}\right)$} & \multicolumn{2}{c|}{ Exterior surface $\left({ }^{\circ} \mathrm{C}\right)$} & \multicolumn{2}{|c|}{ Interior surface $\left({ }^{\circ} \mathrm{C}\right)$} \\
\hline \multirow{3}{*}{ Angle } & $\begin{array}{c}\text { Flow } \\
(\mathrm{m} / \mathrm{s})\end{array}$ & 1 & 2 & 1 & 2 & 1 & 2 \\
\hline \multirow{4}{*}{$45^{\circ}$} & 0 & -5.5 & -5.9 & 0.7 & -1.8 & 15.7 & 11.4 \\
\cline { 2 - 8 } & 1.9 & -6.6 & -6.2 & -3.0 & -3.8 & 15.6 & 11.0 \\
\cline { 2 - 8 } & 3 & -6.9 & -6.4 & -4.8 & -5.2 & 15.0 & 11.0 \\
\hline \multirow{4}{*}{$90^{\circ}$} & 0 & -6.1 & -6.0 & -0.5 & -2.6 & 15.4 & 10.7 \\
\cline { 2 - 8 } & 1.9 & -6.8 & -6.5 & -3.3 & -4.2 & 15.0 & 10.8 \\
\cline { 2 - 8 } & 3 & -7.0 & -6.6 & -4.8 & -5.3 & 14.0 & 10.1 \\
\hline \multirow{3}{*}{$135^{\circ}$} & 0 & -6.2 & -6.1 & -0.7 & -2.9 & 15.8 & 10.5 \\
\cline { 2 - 8 } & 1.9 & -6.6 & -6.3 & -3.3 & -4.0 & 15.0 & 10.5 \\
\cline { 2 - 8 } & 3 & -6.5 & -6.1 & -4.8 & -6.3 & 14.9 & 10.1 \\
\hline \multirow{3}{*}{$180^{\circ}$} & 0 & -5.5 & -5.3 & -0.2 & -2.0 & 15.2 & 10.8 \\
\cline { 2 - 8 } & 1.9 & -5.4 & -5.6 & -0.3 & -2.6 & 15.6 & 11.1 \\
\cline { 2 - 8 } & 3 & -5.4 & -5.6 & -0.4 & -2.6 & 15.6 & 10.8 \\
\hline
\end{tabular}

In cold conditions (negative ambient temperature), where the outside temperature varies significantly from inside, the heat transfer through the glass surface has been more, and as a result, the interior glass temperature has dropped by almost $1^{\circ} \mathrm{C}$. If the test is performed in lower temperatures and for a longer period, the temperature drop on the window surface will probably be even more, especially if the wind speed is higher. Consequently, the experimental results support the CFD simulation, showing a temperature drop on the exterior and interior window surface in windy conditions, particularly in cold climates. In fact, when the wind blows at the window, the air film on the outside of the window is eliminated, leaving the surface colder than before. The results provided by CFD simulation also showed a consistent temperature throughout the interior window surface when the air film existed outside; however, the temperature difference between the bottom and top section of the window increased to $8^{\circ} \mathrm{C}$ when the air film was eliminated. According to the collected data, the temperature difference between the two corner sensors on the interior surface is almost $1^{\circ} \mathrm{C}$ when the exterior ambient 
temperature was $4.6^{\circ} \mathrm{C}$; however, the difference increased to almost $5^{\circ} \mathrm{C}$ when the exterior temperature reduced to $-7^{\circ} \mathrm{C}$. In either scenario, the temperature difference between the two corner sensors remained consistent with increasing air flow. In colder climates, where the exterior temperature varies considerably from the interior, the temperature profile throughout the window interior surface could vary as provided by CFD simulation. In other words, the temperature at the bottom and top of the interior surface could vary considerably due to the downward draft of cold air toward the inside the room.

\subsection{Window II}

The experiment at the second window location was performed on two different occasions; The first one was performed on October 22 $2^{\text {nd }}, 2018$, between 1 to 5 am, where the exterior and interior ambient temperature were recorded to be around $6^{\circ} \mathrm{C}$ and $20^{\circ} \mathrm{C}$, respectively. The second one was performed on December 7th, 2018, between 7 to $11 \mathrm{pm}$, where the exterior and interior ambient temperature were recorded to be around $-3^{\circ} \mathrm{C}$ and $22^{\circ} \mathrm{C}$, respectively.

The window is a double-glazed aluminium window, with an exterior depth of $2.5 \mathrm{~cm}$. The average of seven sensors were calculated for each grid. Two corner sensors were also analyzed. Table 7 shows the first set of average results, which were obtained on October $22^{\text {nd }}$, 2018. 
4.2.1: Set I Results (October 22nd, 2018)

Table 7: Window II Temperature Results (Positive Temperature)

\begin{tabular}{|c|c|c|c|c|c|c|}
\hline Angle & Flow(m/s) & $\begin{array}{l}\text { Exterior Grid } \\
\text { within the } \\
\text { depth }\left({ }^{\circ} \mathrm{C}\right)\end{array}$ & $\begin{array}{c}\text { Exterior grid } 1 \mathrm{~m} \\
\text { from the } \\
\text { window }\left({ }^{\circ} \mathrm{C}\right)\end{array}$ & $\begin{array}{l}\text { Interior grid } \\
\left({ }^{\circ} \mathrm{C}\right)\end{array}$ & $\begin{array}{c}\text { Interior Glass } \\
\text { Surface }\left({ }^{\circ} \mathrm{C}\right)\end{array}$ & $\begin{array}{c}\text { Exterior Glass } \\
\text { Surface }\left({ }^{\circ} \mathrm{C}\right)\end{array}$ \\
\hline \multirow{3}{*}{$45^{\circ}$} & 0 & 8.01 & 5.82 & 23.03 & 20.80 & 10.54 \\
\cline { 2 - 7 } & 1.9 & 5.99 & 5.83 & 22.84 & 20.75 & 8.46 \\
\cline { 2 - 7 } & 3 & 5.85 & 5.62 & 22.84 & 20.19 & 7.18 \\
\hline \multirow{3}{*}{$90^{\circ}$} & 0 & 7.30 & 5.73 & 23.27 & 20.11 & 9.00 \\
\cline { 2 - 7 } & 1.9 & 5.97 & 5.52 & 22.15 & 20.18 & 7.67 \\
\hline \multirow{3}{*}{$135^{\circ}$} & 3 & 5.13 & 5.79 & 22.01 & 19.87 & 5.99 \\
\cline { 2 - 7 } & 1.9 & 7.10 & 5.74 & 22.81 & 19.98 & 8.97 \\
\cline { 2 - 7 } & 3 & 5.91 & 5.66 & 21.73 & 19.95 & 7.91 \\
\hline \multirow{3}{*}{$180^{\circ}$} & 0 & 5.06 & 5.60 & 22.69 & 19.56 & 5.85 \\
\cline { 2 - 7 } & 1.9 & 6.55 & 5.21 & 22.10 & 19.86 & 8.61 \\
\cline { 2 - 7 } & 3 & 6.86 & 5.54 & 21.94 & 19.89 & 9.00 \\
\hline
\end{tabular}

According to the data provided for the first scenario (fan at 45-degree angle), increasing the flow from 0 to $3 \mathrm{~m} / \mathrm{s}$, caused a temperature drop of $3.36^{\circ} \mathrm{C}$ on the external glass and a temperature drop of $0.61^{\circ} \mathrm{C}$ on the internal one. When the fan was set at either 90 degree or 135 degree, the temperature reduction on the external glass was around $3^{\circ} \mathrm{C}$, while on the internal glass was around $0.5^{\circ} \mathrm{C}$. Thus, in all cases, increasing the flow caused a temperature decrease of about $3^{\circ} \mathrm{C}$ on the outside. Additionally, temperature data for sensors 1 and 2 are provided in Table 8. 
Table 8: Positive Temperature Data for Corner Sensors (Window II)

\begin{tabular}{|c|c|c|c|c|c|c|c|}
\hline \multicolumn{2}{|c|}{} & \multicolumn{2}{|c|}{ Exterior depth $\left({ }^{\circ} \mathrm{C}\right)$} & \multicolumn{2}{c|}{ Exterior surface $\left({ }^{\circ} \mathrm{C}\right)$} & \multicolumn{2}{|c|}{ Interior surface $\left({ }^{\circ} \mathrm{C}\right)$} \\
\hline \multirow{3}{*}{ Angle } & $\begin{array}{c}\text { Flow } \\
(\mathrm{m} / \mathrm{s})\end{array}$ & 1 & 2 & 1 & 2 & 1 & 2 \\
\hline \multirow{3}{*}{$45^{\circ}$} & 0 & 8.4 & 8.4 & 11.0 & 8.5 & 20.9 & 19.0 \\
\cline { 2 - 8 } & 1.9 & 5.9 & 6.7 & 9.9 & 8.4 & 20.7 & 19.0 \\
\cline { 2 - 8 } & 3 & 5.6 & 6.0 & 8.0 & 7.2 & 20.0 & 18.7 \\
\hline \multirow{3}{*}{$90^{\circ}$} & 0 & 7.5 & 7.6 & 10.0 & 8.8 & 20.0 & 18.6 \\
\cline { 2 - 8 } & 1.9 & 5.9 & 6.1 & 8.9 & 7.9 & 20.0 & 18.6 \\
\cline { 2 - 8 } $135^{\circ}$ & 3 & 5.8 & 6.1 & 7.7 & 7.1 & 19.7 & 18.3 \\
\cline { 2 - 8 } & 0 & 7.3 & 7.4 & 10.0 & 8.6 & 19.8 & 18.4 \\
\cline { 2 - 8 } & 1.9 & 6.0 & 6.2 & 9.3 & 7.8 & 19.7 & 18.4 \\
\hline \multirow{3}{*}{$180^{\circ}$} & 3 & 5.9 & 5.9 & 7.0 & 6.7 & 19.0 & 18.3 \\
\cline { 2 - 8 } & 0 & 6.9 & 6.9 & 10.0 & 8.2 & 19.7 & 18.3 \\
\cline { 2 - 8 } & 3 & 7.2 & 7.3 & 10.5 & 8.8 & 19.8 & 18.3 \\
\hline
\end{tabular}

The data provided for sensor 1 shows that increasing the air flow decreased the exterior surface temperature by around $3^{\circ} \mathrm{C}$, regardless of the angle. The interior pane temperature also reduced by less than $1^{\circ} \mathrm{C}$ in all cases. In addition, sensor 2 showed a temperature reduction of around $2^{\circ} \mathrm{C}$ on the outside of the glass, while the inside surface temperature remained almost constant. The results for the second window also confirm the CFD simulation, which suggests that the exterior and interior glass temperature falls immediately when the air flow is increased.

\subsection{2: Set II Results (December 7th, 2018)}

The second test was performed on December 7th, 2018 between 7 to $11 \mathrm{pm}$, where the outside temperature was recorded to be around $-3^{\circ} \mathrm{C}$. The results are shown in Table 9 . According to the table, temperature drop on the exterior surface of the window is even more when the ambient temperature is negative. For example, when the fan was set at an angle of $45^{\circ}$, the temperature on the exterior glass surface decreased from $3.25^{\circ} \mathrm{C}$ to $-1.02^{\circ} \mathrm{C}\left(4.27^{\circ} \mathrm{C}\right.$ 
temperature decrease), which caused a temperature drop of $1.27^{\circ} \mathrm{C}$ on the inside. Results from 90-degree angle also provide that increasing the air flow from 0 to $3 \mathrm{~m} / \mathrm{s}$ reduced the temperature on the exterior glass by $4.01^{\circ} \mathrm{C}$ and on the interior glass by $1.11^{\circ} \mathrm{C}$. In addition, when the fan was set at 135 degree, the temperature drop on the external surface was $4.31^{\circ} \mathrm{C}$ and on the internal surface was $1.15^{\circ} \mathrm{C}$. At 180 -degree angle, the temperature change on the window surface is minor, which, again, suggests that a wind flow parallel to the glass, has a minor effect on its temperature.

Table 9: Window II Temperature Results (Negative Temperature)

\begin{tabular}{|c|c|c|c|c|c|c|}
\hline Angle & Flow(m/s) & $\begin{array}{l}\text { Exterior Grid } \\
\text { within the } \\
\text { depth }\left({ }^{\circ} \mathrm{C}\right)\end{array}$ & $\begin{array}{c}\text { Exterior grid } 1 \mathrm{~m} \\
\text { from the } \\
\text { window }\left({ }^{\circ} \mathrm{C}\right)\end{array}$ & $\begin{array}{l}\text { Interior grid } \\
\left({ }^{\circ} \mathrm{C}\right)\end{array}$ & $\begin{array}{c}\text { Interior Glass } \\
\text { Surface }\left({ }^{\circ} \mathrm{C}\right)\end{array}$ & $\begin{array}{c}\text { Exterior Glass } \\
\text { Surface }\left({ }^{\circ} \mathrm{C}\right)\end{array}$ \\
\hline \multirow{3}{*}{$45^{\circ}$} & 0 & -1.12 & -3.02 & 22.78 & 17.73 & 3.25 \\
\cline { 2 - 7 } & 1.9 & -2.39 & -3.01 & 22.86 & 17.00 & 0.33 \\
\cline { 2 - 7 } & 3 & -2.67 & -2.99 & 22.71 & 16.46 & -1.02 \\
\hline \multirow{3}{*}{$90^{\circ}$} & 0 & -1.22 & -2.97 & 22.25 & 17.47 & 3.14 \\
\cline { 2 - 7 } & 1.9 & -2.06 & -2.80 & 22.35 & 17.21 & 0.21 \\
\hline \multirow{3}{*}{$135^{\circ}$} & 3 & -2.32 & -2.72 & 22.85 & 16.36 & -0.87 \\
\cline { 2 - 7 } & 0 & -1.03 & -2.69 & 22.85 & 17.95 & 2.59 \\
\cline { 2 - 7 } & 3 & -2.23 & -2.56 & 22.33 & 17.01 & 0.29 \\
\hline \multirow{3}{*}{$180^{\circ}$} & 1.9 & -2.13 & -2.30 & 21.97 & 16.80 & -1.72 \\
\cline { 2 - 7 } & 3 & -0.42 & -2.13 & 22.18 & 17.27 & 1.13 \\
\cline { 2 - 7 } & 3 & -0.44 & -2.11 & 22.26 & 17.39 & 1.11 \\
\hline
\end{tabular}

Table 10 also provides data for the two corner sensors. According to the experimental results, sensor 2 showed a temperature reduction of around $3^{\circ} \mathrm{C}$ on the exterior surface and a temperature reduction of around $0.5^{\circ} \mathrm{C}$ on the interior, which is less than the average results. Furthermore, sensor 1 showed a temperature decrease of around $4^{\circ} \mathrm{C}$ on the exterior surface and a decrease of around $1^{\circ} \mathrm{C}$ on the interior surface. Comparing sensor 1 data with average results yields an almost similar pattern; to delve into analysis, in windy conditions, the air layer outside 
the window is eliminated, contributing to a lower surface temperature on the external and internal window glasses. Last but not least, data for the second window shows the sensors within the window depth have higher temperatures than the ambient temperature when the flow is zero; but as the flow increases, the temperature immediately falls down to the ambient temperature.

Table 10: Negative Temperature Data for Corner Sensors (Window II)

\begin{tabular}{|c|c|c|c|c|c|c|c|}
\hline \multicolumn{2}{|c|}{} & \multicolumn{3}{|c|}{ Exterior depth $\left({ }^{\circ} \mathrm{C}\right)$} & \multicolumn{2}{c|}{ Exterior surface $\left({ }^{\circ} \mathrm{C}\right)$} & \multicolumn{2}{c|}{ Interior surface $\left({ }^{\circ} \mathrm{C}\right)$} \\
\hline \multirow{4}{*}{ Angle } & $\begin{array}{c}\text { Flow } \\
(\mathrm{m} / \mathrm{s})\end{array}$ & 1 & 2 & 1 & 2 & 1 & 2 \\
\hline \multirow{4}{*}{$45^{\circ}$} & 0 & -0.5 & -0.3 & 3.2 & 2.7 & 18.0 & 15.8 \\
\cline { 2 - 8 } & 1.9 & -2.2 & -2.0 & 1.3 & 1.0 & 17.4 & 15.9 \\
\cline { 2 - 8 } & 3 & -2.7 & -1.7 & -0.4 & -0.6 & 17.0 & 15.4 \\
\hline \multirow{3}{*}{$90^{\circ}$} & 0 & -0.8 & -0.5 & 3.0 & 2.4 & 17.2 & 15.6 \\
\cline { 2 - 8 } & 1.9 & -2.0 & -1.8 & 0.7 & 0.7 & 16.7 & 15.3 \\
\cline { 2 - 8 } & 3 & -2.4 & -2.0 & -0.5 & -0.6 & 16.3 & 15.3 \\
\hline \multirow{4}{*}{$135^{\circ}$} & 0 & -0.7 & -0.3 & 3.6 & 2.8 & 17.0 & 15.5 \\
\cline { 2 - 8 } & 1.9 & -1.2 & -1.7 & 1.3 & 0.5 & 16.6 & 15.4 \\
\cline { 2 - 8 } & 3 & -1.4 & -1.9 & -0.4 & -0.5 & 16.0 & 15.1 \\
\hline \multirow{3}{*}{$180^{\circ}$} & 0 & 0.3 & -0.3 & 2.7 & 2.0 & 16.6 & 15.2 \\
\cline { 2 - 8 } & 1.9 & 0.7 & -0.7 & 3.2 & 2.0 & 16.9 & 15.4 \\
\cline { 2 - 8 } & 3 & 1.0 & -1.3 & 3.4 & 1.0 & 16.9 & 15.6 \\
\hline
\end{tabular}

The collected data also shows that the temperature difference between the two corner sensors on the interior surface is almost $1.5^{\circ} \mathrm{C}$ where the exterior ambient temperature was either $6^{\circ} \mathrm{C}$ or $-3^{\circ} \mathrm{C}$. In either scenario, the temperature difference between the two corner sensors remained consistent with increasing air flow. In colder climates, where the exterior temperature varies considerably from the interior, the temperature profile throughout the window interior surface could vary as provided by CFD simulation. In other words, the temperature at the bottom and top of the interior surface could vary greatly due to the downward draft of cold air toward the inside the room. 


\subsection{Window III}

The experiment at the third window location was performed on October $26^{\text {th }}, 2018$, between 2 to 6 am, where the exterior and interior ambient temperature were recorded to be around $4.5^{\circ} \mathrm{C}$ and $22^{\circ} \mathrm{C}$, respectively.

The window is a double-glazed vinyl window, with an exterior depth of $11 \mathrm{~cm}$. The average of seven sensors were calculated for each grid. Two corner sensors were also examined. Table 11 shows the average results, which were obtained on October $26^{\text {th }}, 2018$.

\subsection{1: Average Results (October 26th, 2018)}

Table 11: Window III Temperature Results (Positive Temperature)

\begin{tabular}{|c|c|c|c|c|c|c|}
\hline Angle & Flow(m/s) & $\begin{array}{l}\text { Exterior Grid } \\
\text { within the } \\
\text { depth( }\left({ }^{\circ} \mathrm{C}\right)\end{array}$ & $\begin{array}{c}\text { Exterior grid } 1 \mathrm{~m} \\
\text { from the } \\
\text { window }\left({ }^{\circ} \mathrm{C}\right)\end{array}$ & $\begin{array}{l}\text { Interior grid } \\
\left({ }^{\circ} \mathrm{C}\right)\end{array}$ & $\begin{array}{c}\text { Interior Glass } \\
\text { Surface }\left({ }^{\circ} \mathrm{C}\right)\end{array}$ & $\begin{array}{c}\text { Exterior Glass } \\
\text { Surface }\left({ }^{\circ} \mathrm{C}\right)\end{array}$ \\
\hline \multirow{3}{*}{$45^{\circ}$} & 0 & 4.68 & 4.36 & 22.38 & 17.37 & 8.77 \\
\cline { 2 - 7 } & 1.9 & 4.57 & 4.48 & 22.04 & 16.73 & 6.61 \\
\cline { 2 - 7 } & 3 & 4.41 & 4.43 & 22.33 & 16.21 & 5.67 \\
\hline \multirow{3}{*}{$90^{\circ}$} & 0 & 4.50 & 4.28 & 22.20 & 16.73 & 8.22 \\
\cline { 2 - 7 } & 1.9 & 4.44 & 4.33 & 22.14 & 16.66 & 6.36 \\
\hline \multirow{3}{*}{$135^{\circ}$} & 3 & 4.38 & 4.31 & 22.11 & 15.91 & 5.55 \\
\cline { 2 - 7 } & 1.9 & 4.60 & 4.21 & 22.07 & 17.00 & 8.22 \\
\cline { 2 - 7 } & 3 & 4.56 & 4.33 & 22.11 & 16.70 & 6.44 \\
\hline \multirow{3}{*}{$180^{\circ}$} & 0 & 4.35 & 4.24 & 21.93 & 15.89 & 5.52 \\
\cline { 2 - 7 } & 1.9 & 4.44 & 4.01 & 21.89 & 16.42 & 7.92 \\
\cline { 2 - 7 } & 3 & 4.30 & 4.10 & 22.19 & 16.66 & 7.85 \\
\hline
\end{tabular}

According to the temperature data provided for the third window, increasing the flow to 3 $\mathrm{m} / \mathrm{s}$ resulted in a temperature reduction of around $3^{\circ} \mathrm{C}$ on the exterior pane and a $1^{\circ} \mathrm{C}$ temperature decrease on the interior pane, regardless of the angle of the fan; however, the exterior and interior glass maintained a consistent temperature when the fan angle was set to 180 degree. 
Two sensors were analyzed separately, as before, to see whether the result would be different than the average one. Table 12 provides the interior and exterior glass temperatures for sensors 1 and 2 .

Table 12: Positive Temperature Data for Corner Sensors (Window III)

\begin{tabular}{|c|c|c|c|c|c|c|c|}
\hline \multicolumn{2}{|c|}{} & \multicolumn{2}{c|}{ Exterior depth $\left({ }^{\circ} \mathrm{C}\right)$} & \multicolumn{2}{c|}{ Exterior surface $\left({ }^{\circ} \mathrm{C}\right)$} & \multicolumn{2}{|c|}{ Interior surface $\left({ }^{\circ} \mathrm{C}\right)$} \\
\hline \multirow{3}{*}{ Angle } & $\begin{array}{c}\text { Flow } \\
(\mathrm{m} / \mathrm{s})\end{array}$ & 1 & 2 & 1 & 2 & 1 & 2 \\
\hline \multirow{3}{*}{$45^{\circ}$} & 0 & 4.9 & 4.9 & 9.4 & 7.8 & 18.4 & 16.0 \\
\cline { 2 - 8 } & 1.9 & 4.4 & 4.6 & 7.3 & 6.0 & 17.7 & 15.6 \\
\cline { 2 - 8 } & 3 & 4.2 & 4.4 & 6.2 & 5.2 & 17.3 & 15.0 \\
\hline \multirow{3}{*}{$90^{\circ}$} & 0 & 4.8 & 4.7 & 9.0 & 7.1 & 17.7 & 15.4 \\
\cline { 2 - 8 } & 1.9 & 4.3 & 4.4 & 6.8 & 5.8 & 17.6 & 15.3 \\
\cline { 2 - 8 } & 3 & 4.2 & 4.4 & 5.8 & 5.1 & 16.9 & 14.8 \\
\hline \multirow{3}{*}{$135^{\circ}$} & 0 & 4.7 & 4.6 & 8.9 & 7.2 & 17.4 & 15.5 \\
\cline { 2 - 8 } & 1.9 & 4.4 & 4.6 & 6.9 & 6.0 & 17.7 & 15.4 \\
\cline { 2 - 8 } & 3 & 4.2 & 4.4 & 5.8 & 5.0 & 16.6 & 14.4 \\
\hline & 0 & 4.5 & 4.7 & 8.7 & 7.2 & 17.4 & 15.2 \\
\cline { 2 - 8 } & 1.9 & 4.8 & 4.2 & 8.7 & 7.4 & 17.7 & 15.3 \\
\cline { 2 - 8 } & 3 & 4.9 & 4.0 & 8.5 & 7.2 & 17.8 & 15.2 \\
\hline
\end{tabular}

According to the table, sensor 2 temperature decreased by $2-2.6^{\circ} \mathrm{C}$ on the external glass and by $0.6-1.1^{\circ} \mathrm{C}$ on the internal pane; Hence, the temperature reduction for sensor 2 is smaller compared to average results. Analyzing sensor 1, on the other hand, shows an almost similar temperature fluctuation pattern as the average results; To delve into analysis deeply, sensor 1 indicates a decrease of more than $3^{\circ} \mathrm{C}$ on the outside glass and a decrease of around $1^{\circ} \mathrm{C}$ on the inside pane. However, in both scenarios, a parallel flow (fan at 180) does not affect the temperature fluctuations on either side of the window glass. Moreover, the sensors with in the exterior depth show a consistent temperature, which is similar to outside temperature; thus, the wind flow only affects the glass sensors. The collected data also shows that the temperature difference between the two corner sensors on the interior surface is consistent with increasing air 
flow and is around $2.5^{\circ} \mathrm{C}$. In colder climates, where the exterior temperature varies greatly from the interior, the temperature profile throughout the window interior surface could vary as provided by CFD simulation. In other words, the temperature at the bottom and top of the interior surface could vary due to the downward draft of cold air toward the inside the room.

The results of experimental window III also comply with CFD simulation, which shows a temperature drop on the exterior and interior glass surface as the air flow increases. In all cases, temperature drop on the interior glass surface was almost $1^{\circ} \mathrm{C}$, which might not be considerable; nevertheless, in colder climates, where the wind speed might be higher as well, the temperature drop will probably be greater, resulting in a greater heat loss from the interior pane. As a result, thermal properties of a window should be improved to prevent additional heat loss to the outside, especially in colder climates, where the temperature differential between outside and inside is high.

"The adoption of American Society of Heating, Refrigerating, and Air-conditioning Engineers (ASHRAE) 90.1, Energy Standard for Buildings Except Low-Rise Residential Buildings, by the Ontario Building Code (OBC)" [10,11] have also moved to improve the energy efficiency of the buildings by reducing glazing percentage. There are other methods of dealing with the energy loss as well. Improving the thermal performance of a window assembly through adding more panes and increasing the space in between them, adding surface films, and replacing the frames with low-conducting material are some of the techniques.

To further enhance the thermal insulation values, the space between the glass panes could be filled with a low conductivity gas like Argon or Krypton at atmospheric pressure [3]. Adding a non-metallic spacer bar between glazing units could also improve the performance [3]. Incorporating composite frames in the windows and using mullions made of low conducting 
material can increase thermal performance of the window system, as well [3]. Moreover, vertical windows are more thermally efficient than the horizontal ones, since they need less backing structure [3].

Window coverings and wind blocking hoods around the window system can also help improve the thermal insulation of the window assembly. Insulated cellular shades (Figure 28) have the highest R-values amongst the several window coverings. They have some air layers in a honeycomb cross-section, which act as insulators, enhancing the R-value of the window [12].

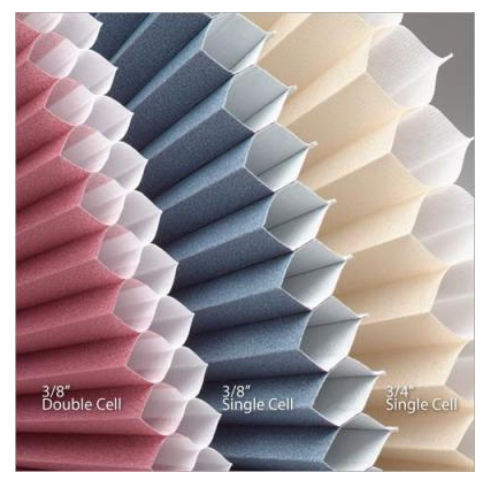

Figure 28: Double Cell and Single Cell Insulated Cellular Shades [12]

Window quilts also improve windows R-value like insulated cellular shades. Drapes could also decrease the window surface temperature significantly if they limit the room air circulation over the assembly [13].

Last but not least, adding automated insulated window shutters on the outside of the building (Figure 29) will decrease energy transfer through glazing in cold climates and will increase insulating properties of the assembly [14]. Incorporating window coverings will also help protect the exterior air film in front of the window glass, which prevents temperature reduction on the surface. 


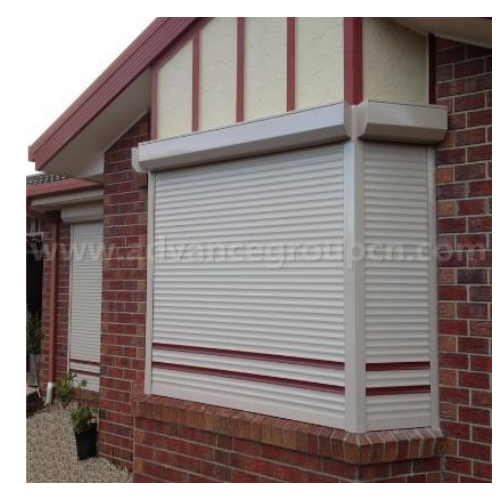

Figure 29: Insulated Exterior Shutters [15]

\subsection{Results for Fan at 180-Degree Angle}

Table 13 provides the temperature results for the three experimental windows when the fan is set at 180 degree with varying flows.

Table 13: Temperature Results for 180-Degree Air Flow (All Windows)

\begin{tabular}{|c|c|c|c|c|c|c|c|c|}
\hline Window & $\begin{array}{c}\text { Temperature } \\
\left({ }^{\circ} \mathrm{C}\right)\end{array}$ & Angle & $\operatorname{Flow}(\mathrm{m} / \mathrm{s})$ & $\begin{array}{l}\text { Exterior } \\
\text { Grid within } \\
\text { the } \\
\text { depth }\left({ }^{\circ} \mathrm{C}\right)\end{array}$ & $\begin{array}{l}\text { Exterior grid } \\
1 \mathrm{~m} \text { from the } \\
\text { window }\left({ }^{\circ} \mathrm{C}\right)\end{array}$ & $\begin{array}{l}\text { Interior } \\
\text { grid }\left({ }^{\circ} \mathrm{C}\right)\end{array}$ & $\begin{array}{c}\text { Interior } \\
\text { Glass Surface } \\
\left({ }^{\circ} \mathrm{C}\right)\end{array}$ & $\begin{array}{c}\text { Exterior } \\
\text { Glass Surface } \\
\left({ }^{\circ} \mathrm{C}\right)\end{array}$ \\
\hline \multirow{3}{*}{ I } & \multirow{3}{*}{4} & \multirow{3}{*}{$180^{\circ}$} & 0 & 4.53 & 4.31 & 19.33 & 15.63 & 6.25 \\
\hline & & & 1.9 & 4.26 & 4.04 & 19.28 & 15.66 & 6.08 \\
\hline & & & 3 & 4.23 & 4.08 & 19.34 & 15.61 & 5.93 \\
\hline \multirow{3}{*}{ I } & \multirow{3}{*}{-6} & \multirow{3}{*}{$180^{\circ}$} & 0 & -6.24 & -6.05 & 20.03 & 13.82 & -1.62 \\
\hline & & & 1.9 & -6.24 & -6.05 & 20.17 & 14.05 & -1.70 \\
\hline & & & 3 & -6.21 & -5.87 & 20.18 & 13.89 & -1.72 \\
\hline \multirow{3}{*}{ II } & \multirow{3}{*}{5.5} & \multirow{3}{*}{$180^{\circ}$} & 0 & 6.55 & 5.21 & 22.10 & 19.86 & 8.61 \\
\hline & & & 1.9 & 6.86 & 5.54 & 21.94 & 19.89 & 9.00 \\
\hline & & & 3 & 6.92 & 5.62 & 23.14 & 20.17 & 9.01 \\
\hline \multirow{3}{*}{ II } & \multirow{3}{*}{-2} & \multirow{3}{*}{$180^{\circ}$} & 0 & -0.42 & -2.13 & 22.18 & 17.27 & 1.13 \\
\hline & & & 1.9 & -0.44 & -2.11 & 22.26 & 17.39 & 1.11 \\
\hline & & & 3 & -0.57 & -2.14 & 22.98 & 17.42 & 1.00 \\
\hline \multirow{3}{*}{ III } & \multirow{3}{*}{4} & \multirow{3}{*}{$180^{\circ}$} & 0 & 4.44 & 4.01 & 21.89 & 16.42 & 7.92 \\
\hline & & & 1.9 & 4.30 & 4.10 & 22.19 & 16.66 & 7.85 \\
\hline & & & 3 & 4.23 & 4.08 & 22.10 & 16.54 & 7.81 \\
\hline
\end{tabular}


According to the data provided, the temperature of the exterior glass surface remained almost consistent during each case, which shows that an air flow parallel to the window did not affect its surface temperature.

One of the research aims was to analyze the effect of an exterior window sill on the glass temperature, which could not be achieved, since a fan was used to create an artificial flow instead of real wind flows. However, temperature data provided for the 180-degree flow direction implies the impact of an exterior window sill on the assembly temperature.

Surface temperature of the experimental windows remained consistent with increasing air flows directed at 180-degree angle; In fact, the exterior sill depth can help protect the air film in front of the window, which increases the surface temperature. On the other hand, wind flow can easily hit a window without an exterior sill and drop its surface temperature by several degrees. As a result, increasing the depth of a window exterior sill can help maintain the protective air film in front of the glass. 


\section{Conclusion}

Glazing system is the weakest part of a building from a thermal performance point of view. In cold climates, where the outside temperature of a building varies greatly from inside, even the best insulating glazing unit becomes a major heat loss, increasing the overall energy use of the building. One of the factors that constitutes a vital portion of a window's insulating value is the exterior air film outside its glass surface. Analyzing a window assembly in computational fluid dynamic showed that in windy conditions, the air film in front of the window opening is eliminated, and the exterior and interior surface temperatures are reduced.

An experimental procedure was performed to validate the CFD simulation for different exterior temperature conditions. The impact of exterior window depth on the assembly temperature had to be examined, as well. The experimental procedure was performed at different exterior temperature conditions, ranging from $-7^{\circ} \mathrm{C}$ to $6^{\circ} \mathrm{C}$, and different flows, ranging from 0 to $3 \mathrm{~m} / \mathrm{s}$. The results for 180-degree flow directed to the windows' surfaces showed that wind had negligible effect on their temperature. In fact, the exterior sill of the windows could help protect the air film in front of the glass, which raised the surface temperature. On the other hand, wind can possibly hit the window glass with no exterior sill, reducing the surface temperature by several degrees. Experimental analysis on all the case study windows also showed a decrease on the surface temperature with increasing air flows at $45^{\circ}, 90^{\circ}$, and $135^{\circ}$ angles. The experimental results showed that even a slow velocity wind could remove the exterior air film, leaving the surface colder than before. The temperature reduction on the glass surfaces could even increase with higher wind flows, particularly in colder conditions. Consequently, the experimental results confirmed the CFD evaluation on window assemblies. In order to reduce additional heat loss to outside, window performance should be improved through incorporating additional panes, 
surface films and low conductive frames and mullions. Also, the space between the glasses should be increased and filled with a low conductivity gas. Increasing the depth of a window's exterior sill and incorporating window coverings such as insulated cellular shades and automated insulated shutters on the outside of a window also help maintain the exterior air film of the glazing. 


\section{Appendix A}

The Code for Arduino Uno:

\#include <OneWire.h>

\#include <DallasTemperature.h>

\#include <SD.h>

\#include <SPI.h>

\#include "RTClib.h"

unsigned long timeNow $=0$;

String cardStatus = "";

int SDcardOK = 10; //1 is true, 0 is false

int LEDpin = 9;

String fileName;

bool record=true;

OneWire ds $18 \times 20[]=\{2,3,4,5,6,7,8\}$;

const int oneWireCount $=$ sizeof $(\mathrm{ds} 18 \times 20) /$ sizeof $($ OneWire $)$;

DallasTemperature sensor[oneWireCount];

File myFile;

int pinCS = 10; // Pin 10 on Arduino Uno

RTC_DS1307 rtc;

//char daysOfTheWeek[7][12] = \{"Sunday", "Monday", "Tuesday", "Wednesday", "Thursday", "Friday", "Saturday"\};

void setup(void) \{ 
// start serial port

Serial.begin(57600);

pinMode(pinCS, OUTPUT);

pinMode(LEDpin, OUTPUT);

//digitalWrite(LEDpin,HIGH);

if (! rtc.begin())

\{

Serial.println("Couldn't find RTC");

while (1);

\}

if (! rtc.isrunning())

\{

Serial.printIn("RTC is NOT running!");

// following line sets the RTC to the date \& time this sketch was compiled

//rtc.adjust(DateTime(F(__DATE_ ), F(_TIME__)));

// This line sets the RTC with an explicit date \& time, for example to set

// January 21, 2014 at 3am you would call:

//rtc.adjust(DateTime(2018, 8, 22, 3, 50, 0));

\}

if(!SD.begin(10))

\{

SDcardOK = 0;

\}

else

\{

SDcardOK = 1;

\} 
Serial.printIn("Dallas Temperature Multiple Bus Control Library Simple Demo");

Serial.print("============Ready with ");

Serial.print(oneWireCount);

Serial.println(" Sensors================");

Serial.println (SDcardOK);

// Start up the library on all defined bus-wires

DeviceAddress deviceAddress;

for (int $\mathrm{i}=0$; $\mathrm{i}<$ oneWireCount; $\mathrm{i}++)\{$;

sensor[i].setOneWire(\&ds18x20[i]);

sensor[i].begin();

if (sensor[i].getAddress(deviceAddress, 0)) sensor[i].setResolution(deviceAddress, 12);

\}

\}

void loop(void) \{

// call sensors.requestTemperatures() to issue a global temperature

$/ /$ request to all devices on the bus

//Serial.print("Requesting temperatures...");

for (int $\mathrm{i}=0$; $\mathrm{i}<$ oneWireCount; $\mathrm{i}++)\{$

sensor[i].requestTemperatures();

\}

//Serial.printIn("DONE");

DateTime now $=$ rtc.now ()

int rtcSecond;

int rtcMinute;

int rtcHour;

int rtcDay;

int rtcMonth; 
int rtcYear;

rtcSecond = now.second();
rtcMinute = now.minute();
rtcHour = now.hour();
rtcDay = now.day();
rtcMonth = now.month();
rtcYear = now.year();

$/ /$ if $(($ rtcHour $>=13 \& \&$ rtcHour $>=20) \& \&($ rtcMinute $<33))$

if $($ rtcHour $>=19 \& \&$ rtcHour $<23)$

//if((rtcHour=9 \&\& rtcMinute $>=1) \& \&($ rtcHour $==9$ \&\& rtcMinute $<=48)) / /$ check if swith is in the ON or OFF position

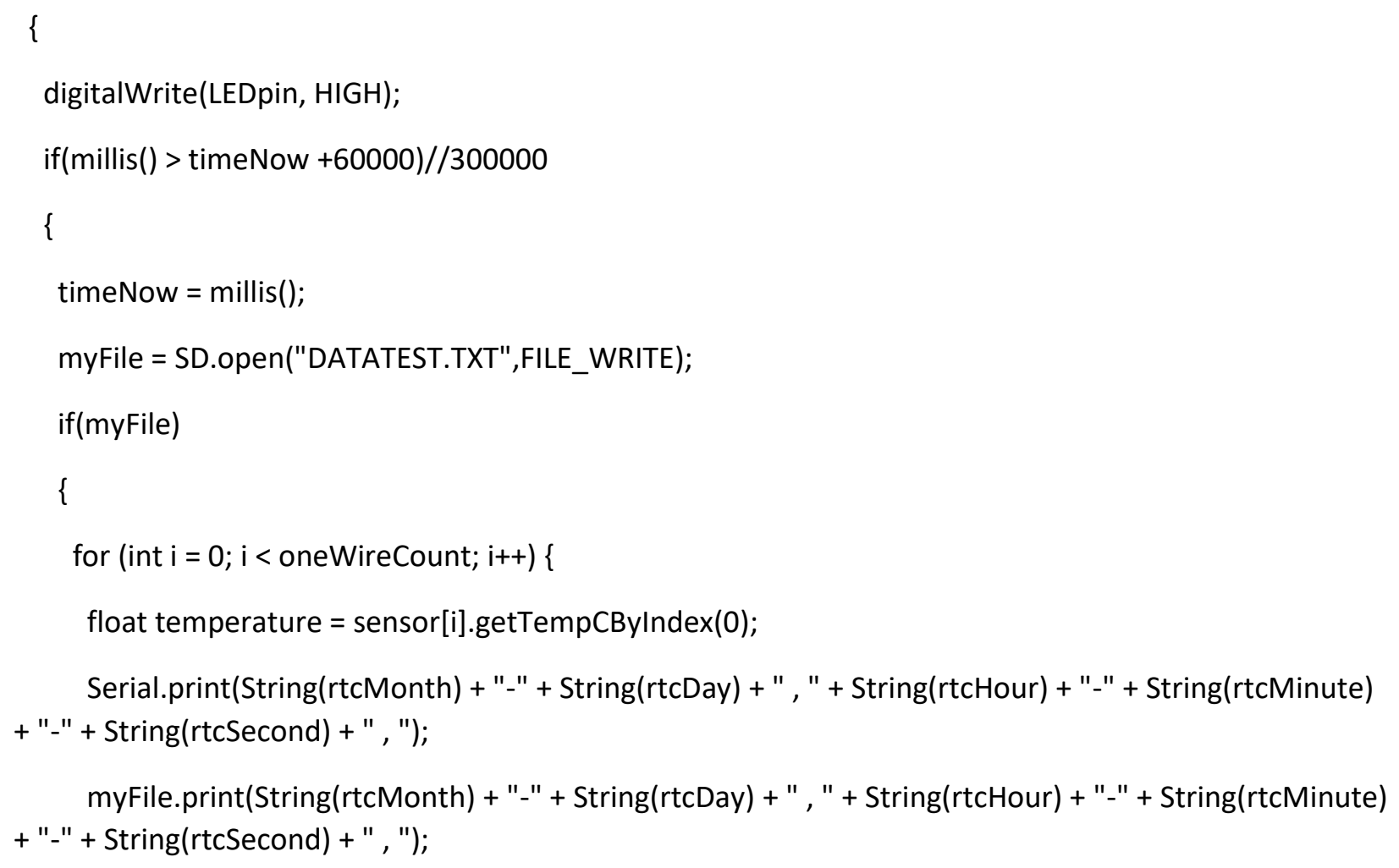


Serial.print("Temperature for the sensor ");

myFile.print("Temperature for the sensor");

Serial.print $(i+2)$;

myFile.print $(i+2)$;

Serial.print(" is ");

myFile.print(" is ");

Serial.println(temperature);

myFile.printIn(temperature);

\}

myFile.close();

\}

\}

\}

Else

\{

Serial.printIn(String(rtcHour) + "-" + String(rtcMinute) + "-" + String(rtcSecond) +" Its not the time yet"); digitalWrite(LEDpin, LOW);

\}

/*

for (int $\mathrm{i}=0 ; \mathrm{i}<$ oneWireCount; $\mathrm{i}++$ ) \{

float temperature $=$ sensor[i].getTempCByIndex(0);

Serial.print("Temperature for the sensor ");

Serial.print(i);

Serial.print(" is ");

Serial.printIn(temperature);

\}

Serial.println();

$* /\}$ 


\section{References}

1. Hutcheon, N. B. and Handegord, G. O., Building Science for a Cold Climate, PP.166, Institute for Research in Construction, National Research Council Canada,1995.

2.Straube, J.F. and Burnett, E.F.P., Building science for building enclosures Building, PP.190, Building Science Press, 2005.

3.Driedger, M., Glazing performance and sustainable design, Construction Canada, May 23, 2014.

4. Adafruit Industries. (n.d.). Waterproof DS18B20 Digital temperature sensor extras. Retrieved from https://www.adafruit.com/product/381

5. Earl, B., Adafruit Data Logger Shield, Adafruit Industries, 2018. Retrieved 2018, from https://cdn-learn.adafruit.com/downloads/pdf/adafruit-data-logger-shield.pdf

6. Arduino Uno. (n.d.). Retrieved from https://www.farnell.com/datasheets/1682209.pdf

7. OCTTEMP 8 Channel Thermocouple Data Logger, MadgeTech, 2012. Retrieved 2018, from https://www.mltest.com/download/octtemp_ds.pdf

8. Ripple, D., and Garrity, K., Uncertainty Budgets for Comparison Calibrations of Thermocouples, National Institute of Standards and Technology, 2005 Retrieved 2018, from https://ws680.nist.gov/publication/get_pdf.cfm?pub_id=830933

9. ABM-200 | Airflow and Environmental Meter. (2018). Retrieved 2018, from https://www.cpsproducts.com/product-details/abm-200/

10. American Society of Heating, Refrigerating and Air-Conditioning Engineers, Standard 90.1, Energy Standard for Buildings Except Low-Rise Residential Building, American National Standards Institute, American Society of Heating, Refrigerating and Air-Conditioning Engineers, and Illuminating Engineering Society of North America, 2013.

11. Ontario Building Code, Ministry of Municipal Affairs and Housing, Housing Development and Buildings Branch, 2006

12. How to Choose the Right Cellular Shade Size. (2017). Retrieved from https://www.blinds.com/blog/how-to-choose-the-right-cellular-shade-size/

13. Gunn, C. (n.d.). Energy Efficient Window Attachments. Retrieved from https://www.energy.gov/energysaver/energy-efficient-window-attachments 
14. Al -Tameemi, L., Deluca, A., Dorfman,L.,Kobeleva,A., Mohamed,A.,Stock, M., Ramakrishnan.R., and Driedger,M., The Impact of Exterior Insulated Shutter Systems, Sustainable Building \& Design Magazine, PP.24, August,2014.

15. Innovative Openings. (n.d.). Exterior Rolling Shutters. Retrieved from https://www.innovativeopenings.com/window-security/exterior-rolling-shutters/ 